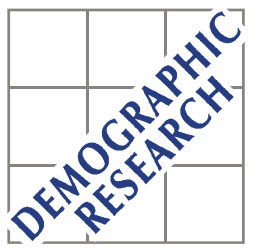

Demographic Research a free, expedited, online journal of peer-reviewed research and commentary in the population sciences published by the Max Planck Institute for Demographic Research Konrad-Zuse Str. 1, D-18057 Rostock · GERMANY www.demographic-research.org

DEMOGRAPHIC RESEARCH

SPECIAL COLLECTION 1, ARTICLE 9

PUBLISHED 19 September 2003, PAGES 279-318

www.demographic-research.org/special/1/9/

DOI: 10.4054/DemRes.2003.S1.9

Research Article

\title{
Why are they worried? \\ Concern about HIV/AIDS in rural Malawi
}

\section{Kirsten P. Smith}

This special collection is edited by Susan Watkins, Eliya M. Zulu, Hans-Peter Kohler and Jere Behrman. The papers in this special collection were presented at the conference "Research on Demographic Aspects of HIV/AIDS in Rural Africa", held at the Population Studies Center, University of Pennsylvania, October 28, 2002.

(C) 2003 Max-Planck-Gesellschaft. 


\section{Table of Contents}

1 Introduction 280

2 Data \& methods $\quad 284$

2.1 Individual factors 286

2.2 Social factors $\quad 288$

$\begin{array}{lll}2.3 & \text { Demographic control variables } & 290\end{array}$

3 Results 291

$3.1 \quad$ Univariate and bivariate results 292

$\begin{array}{lll}3.2 & \text { Multivariate results } & 296\end{array}$

4 Discussion 304

5 Acknowledgements 309

$\begin{array}{ll}\text { Notes } & 310\end{array}$

$\begin{array}{ll}\text { References } & 312\end{array}$ 


\title{
Why are they worried? Concern about HIV/AIDS in rural Malawi
}

\author{
Kirsten P. Smith ${ }^{1}$
}

\begin{abstract}
There are two main types of models of behavioral change. What are collectively referred to as "individual models" are the predominant frameworks for studying risk behaviors including those related to HIV/AIDS. Individual models focus on risk perceptions, attitudes, outcome expectations, perceived norms, and self-efficacy. Models of risk behavior that focus on social or community factors have more recently been developed in response to criticisms of individual models. I use longitudinal data from the Malawi Diffusion and Ideational Change Project to study worry about HIV/AIDS. Specifically, I ask, what factors determine how much a person worries about HIV/AIDS, and are the predominant factors those that individual models would suggest, or are there are other determinants that have a greater impact on worry? I find that levels of network worry and suspected spousal infidelity have the strongest and most robust influence on respondent worry, providing support for the importance of social factors.
\end{abstract}




\section{Introduction}

In the literature on risk behaviors and behavioral change, there are two main types of models. What are collectively referred to as "individual models" are the predominant frameworks for studying risk behaviors, from smoking to unprotected sex. They are also the predominant models used to study HIV/AIDS and its associated risk factors and have been very influential in determining the nature of interventions designed to stem the spread of HIV/AIDS in the developing and developed world. (Aggleton et al. 1994, Bunnell 1996, UNAIDS 1999, Denison 1996). The most influential individual models used to study HIV/AIDS are the Health Belief Model (e.g., Becker 1974, Rosenstock, Strecher, and Becker 1994), the Theory of Reasoned Action (e.g., Fishbein and Ajzen 1975, Ajzen and Fishbein 1980, Fishbein and Middlestadt 1989), Social Cognitive or Learning Theory (e.g., Bandura 1977), Stages of Change (Prochaska, DiClemente, and Norcross 1992), and the AIDS Risk Reduction Model (Catania, Kegeles, and Coates 1990).

To varying degrees, these psychosocial models, created using cognitive-attitudinal and affective-motivational constructs (Kalichman 1998), are individual-centered, focusing on the cognitive process leading to behavioral change (UNAIDS 1999, Denison 1996). Based on the premise that humans control their own behaviors and make decisions that impact those behaviors, these models consider how individuals garner information about a particular behavior, assess its impact, and determine whether they are willing and capable of acting differently. As such, they concentrate on psychological and cognitive factors believed to influence behavioral change: individuals' risk perceptions, attitudes and beliefs regarding risk reduction, outcome expectations (which incorporate beliefs about the severity of a disease and perceived benefits to action), intentions, perceived social norms, and self-efficacy, including perceived barriers to action (Aggleton et al. 1994, UNAIDS 1999, Denison 1996, Kalichman, Rompa, and Coley 1997).

Models and theories of risk behavior that focus on social and community factors operating independently of individual factors have more recently been developed in response to perceived limitations of the traditional cognitive-behavioral, individual models. Purveyors of these newer "social models," which include Diffusion of Innovation theory (Note 1) (Rogers 1983), social inoculation models (e.g., Howard and McCabe 1990), social network theories (e.g., Morris 1997, Auerbach, Wypijewska and Brodil 1994), and theories of gender and power (e.g., Connell 1987, DiClemente and Wingood 1995), argue that behavioral change is not determined solely by individual volition; rather, social relationships and structural and environmental factors constrain people's options for change. According to a UNAIDS review article: 
"[S]ocial researchers have come to realize that because complex health behaviors such as sex take place in context, socio-cultural factors surrounding the individual must be considered in designing prevention interventions." (1999:5)

Consequently, social models concern themselves with influences that derive from social relationships and the community of which the individual is a part.

"Social theories and models see individual behaviors embedded in their social and cultural context. Instead of focusing on psychological processes as the basis for sexual behavior, it tends to be social norms, relationships and gender imbalances that create the meaning and determinants of behavior and behavioral change." (UNAIDS 1999:10)

Factors considered by social models include social pressures, peer influences, cultural expectations, economic factors affecting available resources, legal and political structures, and political and religious ideologies that restrict individuals' options and the flow of information (Aggleton et al. 1994).

One factor postulated implicitly or explicitly by almost all individual theories to affect behavioral change is perceived risk (Bunnell 1996, UNAIDS 1999), which has been described as the most salient feature of these models (Prochaska et al. 1990). The bulk of HIV/AIDS interventions combine elements of various theories of behavioral change, but perceived risk remains a critical construct for even these transtheoretical approaches (UNAIDS 1999). The emphasis placed on perceived risk by theories and interventions is supported by empirical studies that have found perceived risk to be a prerequisite for or correlate of behavioral change (e.g., Cerwonka, Isbell, and Hansen 2000, Dodoo and Ampofo 1998, Estrin 1999, Lupton 1993, Weinstein and Nicolich 1993, Gillies and Carballo 1990).

In this study, I ask, what are the determinants of perceived risk? I also ask, are the dominant factors individual-centered, the type of constructs that individual models of behavioral change (which explicitly incorporate perceived risk) focus on? Or are they social and environmental, the type of constructs that social models of risk behavior argue matter most? I cannot definitively answer the question, "What causes perceived risk?" since mine is a cross-sectional study. But I can explore correlates of perceived risk, proxied through worry. As such, I ask two related questions: what factors are associated with worry about HIV/AIDS, and are they predominantly individual or social in nature?

The data for this study come from interviews conducted in 1998 and 2001 with rural villagers in three areas of Malawi. In this population, worry is a good proxy for 
perceived risk of HIV infection (Note 2). As Figure 1 shows, in Malawi in 2001, current, future, and cumulative risk (defined as the maximum level of reported current or future risk) were strong predictors of worry about HIV/AIDS; respondents who believed that they were already infected or would become infected with HIV/AIDS worried more than did respondents who reported that their risk of infection was negligible. The correlations for men between worry and current and future risk were 0.36 and 0.37 , respectively. The correlations for women were 0.38 and 0.42 , respectively.

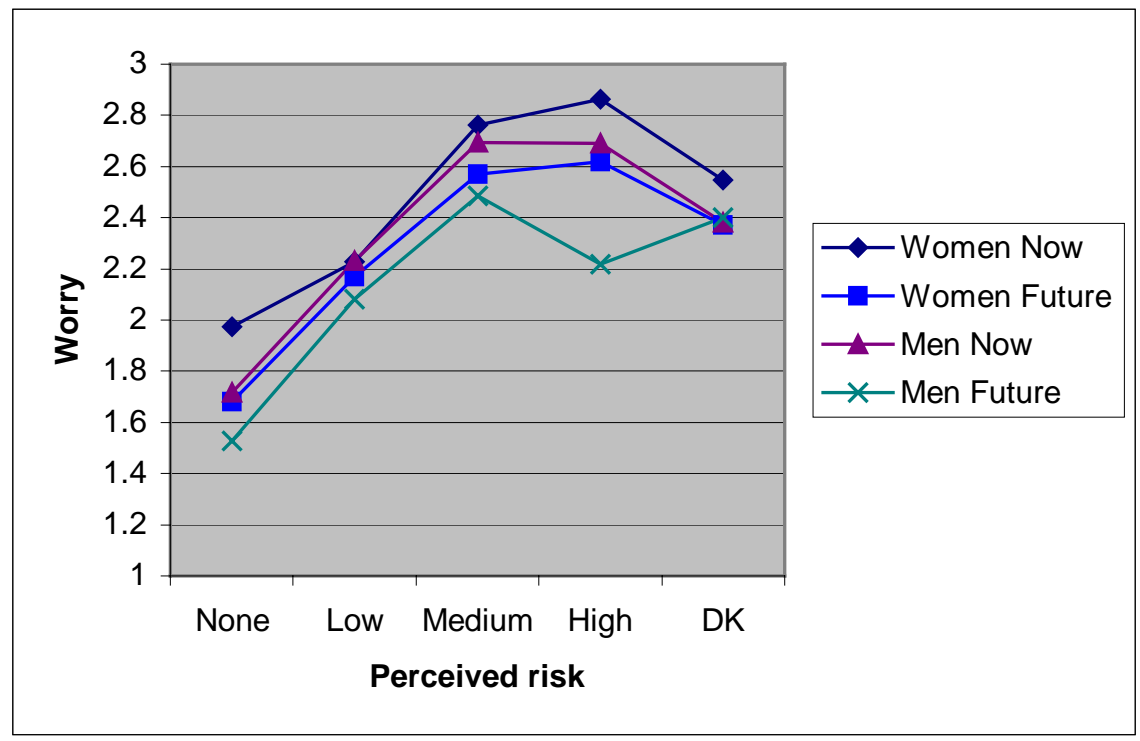

Figure 1: $\quad$ Effect of Perceived Current and Future Risk of HIV Infection on Worry about HIV/AIDS, Women and Men, 2001

Note:

Worry ranges from 1 (not worried) to 3 (very worried).

I chose to focus in this analysis on worry rather than perceived risk for four reasons. First, the data set I use includes two rounds of data on worry but only one on perceived risk. Since my ultimate goal is to contribute to theory building, it is advantageous for 
me to be able to argue that the relationships I document are at least nominally enduring for the population I am studying. This would not be possible were I to have only one wave of data.

Second, worry, like perceived risk, has been linked theoretically and empirically to behavioral change. For example, the Fear Drive Model of behavioral change argues that fear causes discomfort, which in turn motivates behavioral change in order to alleviate the discomfort. The Dual Process Model (Leventhal 1971, Leventhal, Safer, and Panagis 1983) states that when a person feels at risk of an undesirable outcome, he experiences fear, which produces discomfort. He can alleviate the discomfort either by managing the emotion or by eliminating the danger that produces it. The title of the model refers to the two components operating in parallel: fear control, or control of one's emotions, and danger control, or as applied to HIV/AIDS, behavioral change. According to the Fear Reduction Model (Rosenbaum and Heath 1990), information about a potential threat produces a subjective feeling of risk, which in turn produces fear and concern regarding the severity of the potential outcome. Fear and concern motivate behavioral change. Lastly, the Virus of Fear Model (Ostrow 1990), which draws an analogy between the process by which fear and contagion spread, asserts that media-induced fear leads either to positive change or to panic, paralyzation, and feelings of fatalism and hopelessness. Bunnell (1996) points out that in areas with high HIV/AIDS prevalence and limited media penetration, the "fear environment" that results from watching friends and family die from AIDS is probably a more potent "transmitting agent" of fear than is the media.

Third, individual models typically emphasize intentions as an important precursor to behavioral change, and some argue that emotions play an important role in their determination. In fact, models that lack an emotive element have been criticized for failing to explicitly consider the emotional arousal implicit in perceiving that one is at risk of experiencing a negative outcome (Bunnell 1996). In the population I am studying, worry is closely related to perceived risk. Yet worry adds an emotive component that perceived risk lacks, which may render it a better predictor of behavioral change. Lastly, some researchers have questioned the assumption implicit in individual models that people perceive their risk accurately. Because worry is universally experienced and more emotionally based than perceived risk, respondents may have less difficultly understanding the concept of worry and articulating their levels of worry than describing their perceived risk. For the same reasons, worry may also be less prone to translation error (Note 3).

In order to determine what factors contribute to rural Malawians' worry about contracting HIV/AIDS, I constructed a series of ordered categories logistic regression models in which I regress respondents' levels of worry on a number of individual and social factors. What these regressions say overall is that a person's worry about 
contracting HIV/AIDS is little influenced by his own characteristics or behaviors. What does make a difference is the behavior and worries of other people in his life. Whether someone believes her spouse to be unfaithful or not matters. But even more strongly associated with how much a respondent worries is how much people with whom he converses about HIV/AIDS worry. The overall message of this analysis is that social factors are important predictors of worry. Consequently, the assumption implicit in conventional models of health behavior, that individual factors are the primary determinants of perceived risk, is unsupported in this sample of rural Malawians.

Most HIV/AIDS interventions consist of attempts to promote behavioral change, either by educating or providing skills training (UNAIDS 1999, Bunnell 1996). The overall results of these efforts have been disappointing (Bunnell 1996). Some researchers have attributed the lackluster performance of prevention programs to inadequacies in our collective understanding of the process of behavioral change and how it varies across contexts. As the authors of a UNAIDS study observed, "most behavioral models measure risk as individually determined which might not be relevant in many contexts" (UNAIDS 1999:11). By investigating whether perceived risk is influenced by factors other than those postulated by individual models to matter, this study sheds light on the behavioral change process and its contextual variations. On a theoretical level, it broadens understanding of how behavioral change models and risk perception theory can be applied to non-Western contexts. On a practical level, it informs strategies for HIV/AIDS prevention, providing information relevant to the design of effective interventions in Malawi and other high prevalence areas.

\section{Data \& methods}

The data that I use for this study comes from the Malawi Diffusion and Ideational Change Project (MDICP). Survey data were collected during the summers of 1998 and 2001 in three rural districts of Malawi: Rumphi District, located in the northern part of the country, Balaka District, in the south, and Mchinji District, in the central region. Extensive qualitative data also were collected as part of several smaller projects associated with the MDICP. The first round of survey data consists of interviews with 1541 ever-married women of childbearing age (15-49) and 1065 men, husbands of the currently married women. In the second round of data collection, these same respondents and any new spouses were interviewed. Response rates for both waves were high. In 1998, only $1.7 \%$ of men and $1.0 \%$ of women refused to be interviewed. In 2001, the corresponding figures were equally low: $1.8 \%$ and $0.8 \%$, respectively. In regards to attrition, $16 \%$ of males interviewed in the first wave were lost to follow-up. 
Eleven percent of those died between surveys, and $0.5 \%$ were hospitalized or too ill to be re-interviewed. Nineteen percent of the original female sample was lost to followup; $14 \%$ of women not re-interviewed died between surveys, and $1.4 \%$ were ill or in the hospital. The sample is described in greater detail in Watkins et al. (2003). More information is also available at www.pop.upenn.edu/Social_Networks.

The questions that I seek to answer in this study are, what determines how much a person worries about contracting HIV/AIDS, and are the predominant factors those that the prevailing models of health behaviors would suggest, or are there other factors that have a greater impact on the "average" Malawian's level of concern? To answer these related questions, I constructed a series of cumulative logit models for ordered categories analysis. The dependent variable was the respondent's answer to the question, "How worried are you that you might catch AIDS?" Possible answers were "Not worried at all," "Worried a little," "Worried a lot," and "Don't know." In the field, great care was taken by the interviewing team to ensure that the question was translated correctly and consistently. In my analysis, I discarded all cases ( 2 men, 12 women) in which the respondent answered, "Don't know."

The underlying construct, worry, is in theory continuous, but for the purposes of this study, it is measured in discrete categories that range from low to high. Because the distance between categories is not fixed, appropriate methods for analysis need to account for the potentially variable distance between categories. Ordered logit regression, which is also known as cumulative logit regression, is well suited to this task. In an ordered logit regression, the dependent variable consists of $J$ ordered categories, represented by the integers $1,2, \ldots, J$. The $j$ th cumulative odds is the probability of giving a response in category $j$ or lower, as opposed to giving a response in the category $j+1$ or higher. The log of this odds, the Jth cumulative logit, can be modeled as a linear function (Allison 1999).

I selected my independent variables based on what the literature, models of health behavior, and qualitative work associated with the MDICP survey suggested might impact respondent worry about HIV/AIDS. For a detailed listing of the variables analyzed, see Table 2. Empty cells in the table correspond to questions that were not asked for that particular sex and wave. The variables of interest were divided into two groups, individual and social, according to the underlying constructs they measure. Individual factors tested consist of behaviors, knowledge and beliefs, and proxies for outcome expectations. Social factors tested consist of perceptions of spouses' behavior, characteristics of respondents' HIV/AIDS conversational networks, and community markers. Since I lack adequate measures for capturing every salient component of any given behavioral change model or theory, the purpose of this analysis is not so much to refute the validity of a class of models as to argue for the importance of factors neglected by that class. 
I restricted the analysis to respondents interviewed in both waves and with no missing data for the variables of interest. I also excluded respondents who reported having discussed AIDS with no one (74 men, 221 women) or who did not know how worried at least one of their conversational network partners was (14 men, 17 women), yielding a total of 878 women and 660 men. Analyzing males and females separately, I conducted bivariate tests of association with worry for each variable in each wave. To determine which relationships were significant after controlling for other relevant factors, I combined the variables that were significant in the bivariate models in a series of nested multivariate models. To qualify for inclusion, a variable had to be longitudinal and at least marginally significant for either sex in either wave. Data were collected in 145 villages in the first wave and 152 villages in the second wave. To adjust for the possibility that observations were not independent within villages, I used the Huber/White/sandwich estimator of variance method to calculate robust standard errors in all models. I also used likelihood ratio tests to confirm that models with social variables provided a significantly better fit to the data than did models without them.

The prevalence of HIV infection in Malawi ranks among the highest in the world. At the end of 1999, an estimated $16 \%$ of adults were sero-positive (UNAIDS/WHO 2000). According to government estimates based on sentinel surveillance data from antenatal clinics, $17 \%$ of pregnant women in Mchinji were HIV positive in 1998. In Rumphi, the figure was $12.5 \%$, and in Balaka, it was $14.9 \%$ (National AIDS Control Programme 1998). Despite the high prevalence of HIV/AIDS in Malawi, few people get tested for HIV. For the purposes of this analysis, I assume that most people do not know their HIV status. I also assume that those who do know or suspect that they have HIV/AIDS will report that they are more rather than less worried about contracting the disease. Given the afore-mentioned positive association between believing that you already have AIDS and reporting that you are worried about contracting it, this seems a safe assumption.

\subsection{Individual factors}

Behaviors. Two basic tenets in the theoretical and empirical literature on behavioral change are that high perceived risk prompts the adoption of protective behaviors, and positive behavioral change in turn reduces perceived risk (Weinstein and Nicolich 1993, Bunnell 1996). The reciprocity of this relationship points to the need for establishing sequential ordering when analyzing associations between perceived risk and behavioral change. The MDICP contains no direct measure of behavioral change in response to HIV/AIDS and only one indirect measure, previous experience with condoms. Unfortunately, this variable lacks a time referent, which opens up its analysis to the 
problem of reverse causation. But because unprotected sex is a major HIV risk factor and consistent condom use a widely promoted strategy for avoiding HIV/AIDS, I decided to look at it regardless.

I looked at the effects of two behavioral constructs on respondent worry: previous experience with condoms and having engaged in extramarital sex. For the former, I used a variable constructed from questions regarding past condom use as a form of contraception and with premarital and extramarital partners (Note 4). To measure extramarital sexual activity, I used two indirect and one direct measure, answers to the question, "Have you yourself slept with anyone other than your husband/wife in the last 12 months" (Note 5). The indirect measures that I used were answers to two questions regarding time spent away from home. The first question asked whether the respondent had spent more than one month of the past year away. The second asked whether the respondent (if male) or her husband (if the respondent was female) usually "stays" in his wife's village. Qualitative accounts suggest that men and women regard extended spousal separations as opportunities for both spouses to stray, and an extensive literature has argued that by separating husbands and wives for lengthy periods of time, labor migration promotes extramarital sexual activity, thereby contributing to the spread of HIV/AIDS in sub-Saharan Africa (Packard and Epstein 1991, Aggleton et al. 1994, Quinn 1994, Hunt 1996).

Knowledge/beliefs. Individual models of health behavior regard knowledge and beliefs as important predictors of behavioral change (Bunnell 1996). Past research has found that HIV/AIDS-related knowledge is significantly related to AIDS-related worry (Klepinger et al. 1993), perceived risk (London and Robles 2000), and behavioral change (Gregson et al. 1998). I test whether worry is related to four indicators of knowledge about HIV/AIDS. The first variable indicates respondents' awareness that even people who appear healthy may be HIV positive. The second measures beliefs regarding the infectiousness of HIV (Note 6). The third variable, answers to the question, "If a person gets very thin and dies, what disease do you think probably killed them?", indicates an awareness of the presence of HIV/AIDS in the community and a willingness to attribute local deaths to the disease.

One factor explicitly considered by individual models to affect behavioral change is exposure to information about a potential threat. Previous research documented a positive relationship between exposure to HIV/AIDS information and both worry (Klepinger et al. 1993, Gregson et al. 1998) and perceived risk (London and Robles 2000). The final variable in the series is therefore a measure of exposure to HIV/AIDS information from "expert" (as opposed to lay) sources. Values range from zero (having had no exposure) to three (having received information from a community-based health officer, a hospital or clinic, and via the radio). 
Outcome Expectations. Individual theories emphasize that before people will be motivated to avoid behaviors that put them at risk of acquiring an illness, they must first believe that having that illness is both undesirable and avoidable. Two variables-number of funerals attended in the past month and number of acquaintances suspected to have died of HIV/AIDS--indirectly measure respondents' beliefs in the severity of HIV/AIDS and the threat it poses. They also serve as rough proxies for perceived prevalence of death due to AIDS (Note 7).

\subsection{Social factors}

Spouse. Individual models of HIV/AIDS-related behavioral change have been criticized for giving inadequate attention to the role of spouses in facilitating or impeding change (Denison 1996). In my sample of ever-married women and their husbands, the behavior of current and ex-spouses constitutes a major source of past or current HIV risk. The first variable in this series is therefore marital status. I include the full four-category version of this variable in Table 2 for interest only, as most of the categories have too few cases to allow for analyzing them separately. I distinguish between monogamous and polygynous unions in the operational version of this variable because polygyny has been shown by other studies to be positively associated with perceived risk of HIV infection (Bunnell 1996). The second variable in the series is respondents' perceptions of their spouses' fidelity. Respondents were asked whether they know or suspect that their spouse has had extramarital sex during the course of their marriage. Possible answers were "Yes" or "Suspect," "Don't know" or "Can't know what (s)he does," and "Probably not." Respondents who answered "Probably not" but reported elsewhere in the survey that their greatest risk of HIV/AIDS infection comes from their spouse were recoded "Can't/Don't know." The third variable in this series is answers to a question regarding the acceptability of using a condom with a spouse.

Social models emphasize that social and cultural factors must be considered when accounting for behavioral change or lack thereof. One factor frequently blamed for the spread of HIV/AIDS in sub-Saharan Africa and the unusually high percentage of women that are infected is women's inferior position relative to men (Caldwell, Caldwell, and Orubuloye 1989, Caldwell and Caldwell 1993, Chirwa 1993, Dodoo and Ampofo 1998, McGrath et al. 1993, Ntozi and Kirunga 1997, Ray et al. 1995, Ray, Gumbo, and Mbizvo 1996, Van de Wijgert et al. 1999, Watts et al. 1998). The basic argument is that a multitude of factors forces women to "submit to their partner's [sic] demands for sex" (Watts et al. 1998), impeding their ability to protect themselves against HIV infection. Foremost among these factors is women's financial dependence 
on their sexual partners due to limited economic opportunities for women. In its extreme form, this dependence drives women into prostitution (Caldwell and Caldwell 1993, Quinn 1994). In its milder form, it reduces their ability to leave unfaithful lovers or husbands and to insist on condom use during sex with risky partners (Aggleton et al. 1994). The fourth variable in this series is therefore whether or not the respondent herself reports earning money, either in cash or kind. If it is the case that, by eliminating their ability to deny sex, women's financial dependence on their sexual partners increases their risk of contracting HIV/AIDS, then women with no independent income should worry more about HIV/AIDS than should women with independent income (Note 8). In support of this hypothesis, research in Zimbabwe (Watts et al. 1998) found that women with earnings worry less about HIV/AIDS than do women without earnings. Conversely, if men use cash or financial clout to effectively "purchase" sex-or at least, control over sex--then men with no independent income, because their access to payment and influence is reduced, might worry less about HIV/AIDS. Since previous research (Garnet and Anderson 1993) has suggested that the tradition in sub-Saharan Africa of women marrying substantially older men has contributed to the rapid spread of HIV/AIDS in the region, the final variable in this series is respondents' reports of the difference between their and their current or most recent spouse's age.

AIDS Conversational Networks. A central tenet of social theories of health behavior is that social norms and relationships have a profound influence on people's understandings of social phenomena and their motivations to change. According to this view, the opinions and actions of those with whom a rural Malawian discusses HIV/AIDS will play a significant role in shaping her own opinions and actions. The variables concerning respondents' HIV/AIDS conversational networks assess the magnitude of that influence in regards to worry about HIV/AIDS. Respondents were asked with how many people they had chatted about HIV/AIDS; their answers constitute the first variable in the series. They were then asked a number of HIV/AIDSrelated questions regarding up to four of these conversational, or network, partners. The second variable is the number of network partners reported on (maximum of four). The third variable indicates having a least one network partner who is moderately or very worried about HIV/AIDS. The fourth variable is the number of network partners who are moderately or very worried about HIV/AIDS. The final variable in the series is the average level of worry of one's network partners. Ranging from 1 (not worried) to 3 (very worried), it was constructed by summing the worry of each network partner and dividing the total by the number of partners (Note 9). To determine whether the influence on respondent worry of network-partner worry depends on the size of respondents' networks, I tested for an interaction between the two variables; when the interaction term was significant in the bivariate models, it was retained in the 
multivariate models. Because the network variables were highly collinear, I included only number of network partners and average partner worry in the multivariate models.

Community Markers. Social theories emphasize the importance of environment and social context in facilitating or impeding behavioral change. I include the final set of variables, community markers, as indictors of extended social networks and cultural or social environments that might impact respondents' experiences with HIV/AIDS. Some of the variables denote membership in cultural groupings (e.g., religious affiliation and ethnicity). Others, like region of residence, more abstractly assume that people living in close proximity share similar cultural ideologies and social structures (e.g., political, legal, and economic ideologies and structures) that shape their responses to HIV/AIDS. The first variable in this series is religious affiliation. This variable was coded differently in each wave, so to make the waves comparable, I combined the categories "Protestant," "Revivalist," and "Traditional." The second variable, answers to a question regarding the last time the respondent attended a religious service, measures religiosity. The last two variables in this series are ethnic identification and region of residence.

\subsection{Demographic control variables}

I control for age, education (specifically, the highest level of schooling attended), and household wealth in the multivariate models. The wealth index, which ranges from 0 (poor) to 13.7 (rich), is a relative measure constructed by summing the number of household items a respondent owns, weighted by the likelihood of owning each item in the survey population. The possessions considered were a bed, sofa, lantern, bicycle, metal roof, plough, and pit latrine.

I include education as a control variable because it has been shown to be associated in sub-Saharan Africa with both fear (Ntozi and Kirunga 1997) and actual risk (Dodoo and Ampofo 1998) of contracting HIV/AIDS. Research has shown that over the last decade, highly educated people responded to the HIV/AIDS epidemic by altering their AIDS-related behaviors to a greater extent than did less educated people (Ntozi and Kirunga 1997, UNAIDS/WHO 2000). As a result, whereas in the early 1990s, risk of infection was positively associated with education, by the end of the decade, the relationship had reversed (UNAIDS/WHO 2000). I control for age because

it, too, has been found to be associated with worry about HIV/AIDS (Ntozi and Kirunga 1997). 
Demographic Research - Special Collection 1: Article 9

-- Social Interactions and HIV/AIDS in Rural Africa --

Table 1: Worry and Perceived Risk, Frequencies and Relationships with Worry, Women and Men, 1998 and 2001

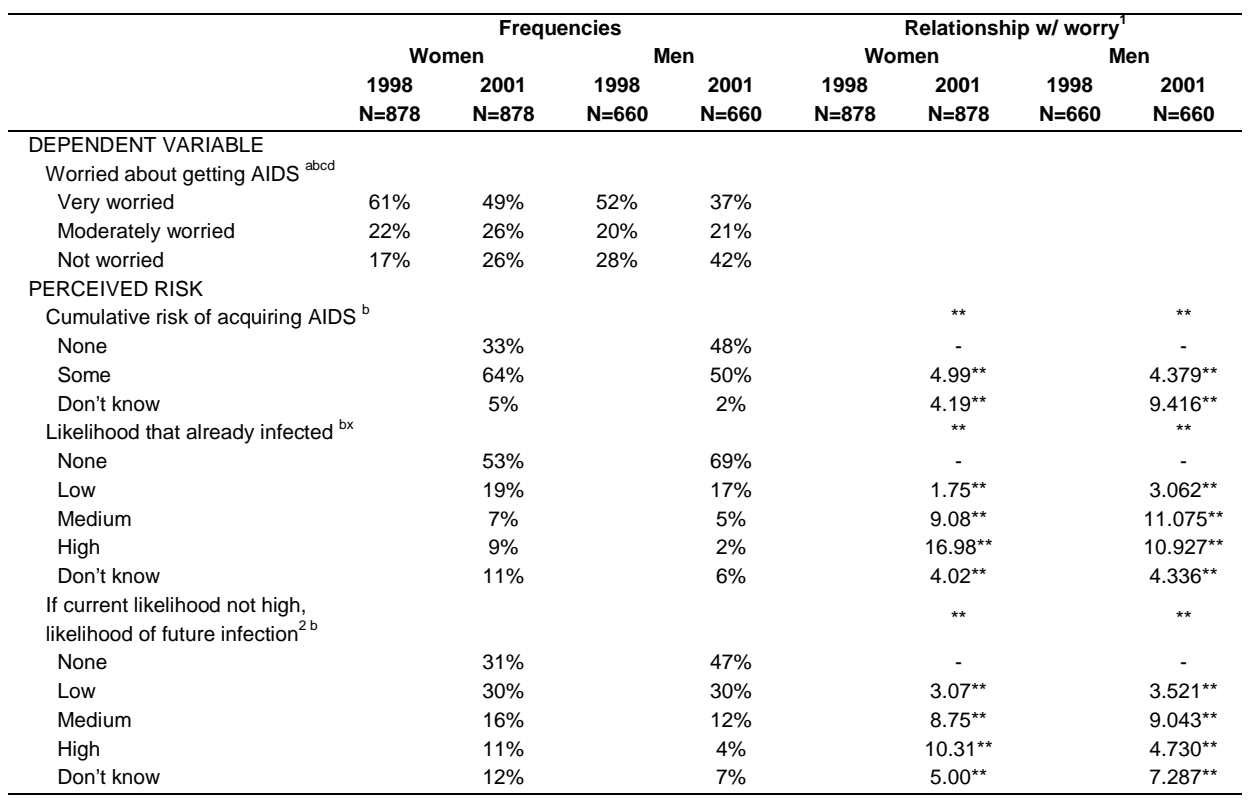

Notes:

Overall significance of polytomous categorical variables indicated in first line of variable results.

+ significant at $\mathrm{p}<10 \%$; ${ }^{*}$ significant at $\mathrm{p}<5 \%$; ${ }^{* *}$ significant at $\mathrm{p}<1 \%$.

${ }^{1}$ Results of ordered logistic regressions with worry. Figures presented are odds ratios. Robust standard errors used to calculate $\mathrm{p}-$ values.

${ }^{2}$ Restricted to respondents who did not report that their current risk of infection is high.

${ }^{a}$ Significant $(p<5 \%)$ difference between frequencies for women and men in 1998 . Results from $\chi^{2}$ test.

${ }^{b}$ Significant $(p<5 \%)$ difference between frequencies for women and men in 2001. Results from $\chi^{2}$ test.

${ }^{c}$ Significant $(p<5 \%)$ difference between frequencies for men in 1998 and 2001. Results from $\chi^{2}$ test.

${ }^{d}$ Significant $(p<5 \%)$ difference between frequencies for women in 1998 and 2001 . Results from $\chi^{2}$ test.

${ }^{x}$ Significant $(p<5 \%)$ difference between women and men in effect on worry in 2001.

\section{Results}

Levels of worry in this sample are high, as shown in Table 1. In 1998, approximately three-quarters of respondents reported that they worry about AIDS, although by 2001, the proportion had declined to two-thirds. Worry declined over time for both sexes, although in both waves, women were more likely than men to report being worried. Women also were more likely to report that they already have HIV/AIDS or will eventually contract it. Only $5 \%$ of women and $2 \%$ of men report that they do not know 
their risk of either having or contracting HIV/AIDS. The literature on HIV/AIDS in Africa resounds with descriptions of the stigma associated with HIV/AIDS and people's unwillingness to publicly entertain the possibility of their having it. The MDICP data do not support this view, as evident in the nontrivial percentage of respondents who report that the likelihood that they are currently infected is high.

\subsection{Univariate and bivariate results}

The results of the univariate and bivariate analyses are presented in Table 2. In this section, I will restrict my discussion of results to variables excluded from the multivariate analyses because they are not longitudinal or are not significantly related to worry.

Table 2: $\quad$ Individual and Social Factors, Frequencies and Relationships with Worry, Women and Men, 1998 and 2001

\begin{tabular}{|c|c|c|c|c|c|c|c|c|}
\hline & \multicolumn{4}{|c|}{ Frequencies } & \multicolumn{4}{|c|}{ Relationship w/ worry $^{1}$} \\
\hline & \multicolumn{2}{|c|}{ Women } & \multicolumn{2}{|c|}{ Men } & \multicolumn{2}{|c|}{ Women } & \multicolumn{2}{|c|}{ Men } \\
\hline & 1998 & 2001 & 1998 & 2001 & 1998 & 2001 & 1998 & 2001 \\
\hline & $\mathrm{N}=878$ & $\mathrm{~N}=878$ & $\mathrm{~N}=660$ & $\mathrm{~N}=660$ & $\mathrm{~N}=878$ & $\mathrm{~N}=878$ & $\mathrm{~N}=660$ & $\mathrm{~N}=660$ \\
\hline \multicolumn{9}{|l|}{ INDIVIDUAL FACTORS } \\
\hline \multicolumn{9}{|l|}{ BEHAVIORS } \\
\hline Had extramarital sex in past year ${ }^{\text {ab }}$ & $2 \%$ & $3 \%$ & $11 \%$ & $10 \%$ & $2.69+$ & NS & NS & $2.20^{* *}$ \\
\hline Ever used condoms abcd & $3 \%$ & $9 \%$ & $17 \%$ & $34 \%$ & NS & $1.63^{*}$ & $1.49^{*}$ & NS \\
\hline Spent $>1$ month of past year away ${ }^{b}$ & & $9 \%$ & & $18 \%$ & & NS & & NS \\
\hline Husband stays in wife's village ${ }^{\text {abcd } z}$ & $84 \%$ & $87 \%$ & $94 \%$ & $97 \%$ & $0.41^{* *}$ & NS & $0.35^{*}$ & NS \\
\hline \multicolumn{9}{|l|}{ KNOWLEDGE } \\
\hline Knows cannot tell HIV status by how someone looks ${ }^{y}$ & $93 \%$ & $93 \%$ & $93 \%$ & $95 \%$ & $0.45^{\star \star}$ & NS & $0.34^{* *}$ & NS \\
\hline $\begin{array}{l}\text { Likelihood of infection if have sex once } w / \text { infected } \\
\text { person }{ }^{x}\end{array}$ & & & & & & * & & ** \\
\hline None/low & & $3 \%$ & & $3 \%$ & & $0.34^{*}$ & & $1.97+$ \\
\hline High & & $30 \%$ & & $29 \%$ & & NS & & $1.54^{\star *}$ \\
\hline Certain & & $67 \%$ & & $68 \%$ & & - & & - \\
\hline If get thin and die it's... ${ }^{a}$ & & & & & NS & & MS & \\
\hline AIDS & $90 \%$ & & $82 \%$ & & - & & - & \\
\hline AIDS or witchcraft & $4 \%$ & & $7 \%$ & & NS & & $1.62+$ & \\
\hline Other & $6 \%$ & & $11 \%$ & & NS & & $1.50+$ & \\
\hline & 2.0 & 2.3 & 2.2 & 2.4 & & & & \\
\hline \# sources of HIV/AIDS information exposed to abcd w & $(0.7)$ & $(0.6)$ & $(0.7)$ & $(0.6)$ & $1.64^{\star *}$ & $1.36^{\star \star}$ & NS & $1.38^{*}$ \\
\hline & [2] & [2] & [2] & [2] & & & & \\
\hline \multicolumn{9}{|l|}{ OUTCOME EXPECTATIONS } \\
\hline \# funerals attended in past month ${ }^{b}$ & & & & & & NS & & NS \\
\hline 0 & & $4 \%$ & & $5 \%$ & & NS & & NS \\
\hline $1-3$ & & $48 \%$ & & $36 \%$ & & - & & - \\
\hline 4-6 & & $32 \%$ & & $38 \%$ & & NS & & NS \\
\hline $7+$ & & $16 \%$ & & $21 \%$ & & NS & & NS \\
\hline
\end{tabular}


Demographic Research - Special Collection 1: Article 9

-- Social Interactions and HIV/AIDS in Rural Africa --

\begin{tabular}{|c|c|c|c|c|c|c|c|c|}
\hline & \multicolumn{4}{|c|}{ Frequencies } & \multicolumn{4}{|c|}{ Relationship w/ worry $^{1}$} \\
\hline & \multicolumn{2}{|c|}{ Women } & \multicolumn{2}{|c|}{ Men } & \multicolumn{2}{|c|}{ Women } & \multicolumn{2}{|c|}{ Men } \\
\hline & 1998 & 2001 & 1998 & 2001 & 1998 & 2001 & 1998 & 2001 \\
\hline & $\mathrm{N}=878$ & $\mathrm{~N}=878$ & $N=660$ & $\mathrm{~N}=660$ & $\mathrm{~N}=878$ & $\mathrm{~N}=878$ & $\mathrm{~N}=660$ & $\mathrm{~N}=660$ \\
\hline \# suspected to have died of AIDS & & & & & NS & NS & * & NS \\
\hline 0 & $4 \%$ & $2 \%$ & $4 \%$ & $2 \%$ & NS & NS & $3.10^{*}$ & NS \\
\hline $1-5$ & $53 \%$ & $46 \%$ & $49 \%$ & $47 \%$ & NS & NS & NS & NS \\
\hline $6-15$ & $19 \%$ & $40 \%$ & $25 \%$ & $37 \%$ & NS & NS & $1.50^{*}$ & NS \\
\hline $16+$ & $22 \%$ & $11 \%$ & $21 \%$ & $13 \%$ & - & - & - & - \\
\hline Don't know & $2 \%$ & $2 \%$ & $2 \%$ & $1 \%$ & $4.05^{\star}$ & NS & NS & NS \\
\hline \multicolumn{9}{|l|}{ SOCIAL FACTORS } \\
\hline \multicolumn{9}{|l|}{ PERCEPTIONS OF SPOUSES' BEHAVIOR } \\
\hline \multicolumn{9}{|l|}{ Marital status ${ }^{a b}$} \\
\hline Married & $90 \%$ & $91 \%$ & $99 \%$ & $97 \%$ & & & & \\
\hline Separated & $2 \%$ & $1 \%$ & $0 \%$ & $0 \%$ & & & & \\
\hline Divorced & $6 \%$ & $5 \%$ & $1 \%$ & $2 \%$ & & & & \\
\hline Widowed & $2 \%$ & $3 \%$ & $0 \%$ & $1 \%$ & & & & \\
\hline Marital status ${ }^{a b c d x z}$ & & & & & ** & ** & NS & NS \\
\hline Not married & $10 \%$ & $9 \%$ & $1 \%$ & $3 \%$ & $2.03^{* \star}$ & NS & NS & NS \\
\hline Monogamous union & $69 \%$ & $70 \%$ & $85 \%$ & $81 \%$ & - & - & - & - \\
\hline \multirow[t]{2}{*}{ Polygynous union } & $21 \%$ & $21 \%$ & $14 \%$ & $16 \%$ & $1.64^{\star \star}$ & $2.25^{\star \star}$ & NS & NS \\
\hline & & 1.5 & & 1.7 & & & & \\
\hline \multirow[t]{2}{*}{ \# times been married ${ }^{\mathrm{b}}$} & & $(0.7)$ & & $(1.0)$ & & $1.18^{*}$ & & $1.20^{*}$ \\
\hline & & [1] & & 2 & & & & \\
\hline Opinion of fidelity of spouse ${ }^{a b c d}$ & & & & & ** & ** & ** & + \\
\hline Unfaithful/suspects unfaithful & $28 \%$ & $27 \%$ & $7 \%$ & $4 \%$ & $2.04^{\star \star}$ & $2.30^{\star \star}$ & $2.43^{*}$ & $1.86+$ \\
\hline Can't/don't know & $36 \%$ & $46 \%$ & $24 \%$ & $32 \%$ & $1.57^{\star}$ & $1.98^{\star *}$ & $1.91^{* *}$ & NS \\
\hline Probably faithful & $36 \%$ & $27 \%$ & $68 \%$ & $64 \%$ & - & - & - & - \\
\hline Says OK to use condom w/ spouse ${ }^{\text {abcd } y}$ & $13 \%$ & $29 \%$ & $10 \%$ & $24 \%$ & $2.23^{\star \star}$ & $2.01^{\star \star}$ & $2.92^{\star *}$ & $1.52^{*}$ \\
\hline Difference in spouses' ages ${ }^{b}$ & & & & & & NS & & NS \\
\hline Wife $6+$ years older & & $2 \%$ & & $7 \%$ & & NS & & NS \\
\hline About the same age & & $46 \%$ & & $48 \%$ & & - & & - \\
\hline Wife $6-10$ years younger & & $35 \%$ & & $30 \%$ & & NS & & NS \\
\hline Wife $11+$ years younger & & $10 \%$ & & $12 \%$ & & NS & & NS \\
\hline Don't know & & $7 \%$ & & $3 \%$ & & NS & & NS \\
\hline Earns income ${ }^{\text {abd z }}$ & $77 \%$ & $81 \%$ & $98 \%$ & $99 \%$ & NS & NS & NS & NS \\
\hline \multicolumn{9}{|l|}{ CONVERSATIONAL NETWORKS } \\
\hline \multirow{4}{*}{ \# chatted with about HIV/AIDS ${ }^{\text {abd } x z}$} & 5.2 & 6.4 & 6.9 & 7.3 & & & & \\
\hline & $(5.4)$ & $(5.6)$ & $(6.6)$ & (7.1) & NS & $1.03^{\star}$ & $0.97^{*}$ & NS \\
\hline & [4] & {$[4]$} & {$[4]$} & [4.5] & & & & \\
\hline & 3.0 & 3.6 & 3.4 & 3.6 & & & & \\
\hline \multirow[t]{2}{*}{ \# network partners (NPs) ${ }^{\text {acd } x}$} & (1.1) & $(0.8)$ & $(0.9)$ & $(0.7)$ & NS & NS & NS & NS \\
\hline & [3] & {$[4]$} & {$[4]$} & {$[4]$} & & & & \\
\hline \multirow[t]{2}{*}{ At least one NP worried ${ }^{\text {cd wxy }}$} & $90 \%$ & $84 \%$ & $87 \%$ & $81 \%$ & $5.75^{\star \star}$ & $3.76^{\star \star}$ & $13.82^{\star \star}$ & $5.79^{* *}$ \\
\hline & 2.4 & 2.1 & 2.5 & 2.1 & & & & \\
\hline \multirow[t]{3}{*}{ \# NPs worried ${ }^{\text {cd wx }}$} & (1.3) & (1.3) & $(1.4)$ & (1.4) & $1.73^{* *}$ & $1.68^{\star \star}$ & $2.10^{* *}$ & $2.10^{* *}$ \\
\hline & [2] & [2] & [3] & [2] & & & & \\
\hline & 2.4 & 2.0 & 2.3 & 1.9 & & & & \\
\hline \multirow[t]{2}{*}{ Average NP worry ${ }^{c d w x}$} & $(0.7)$ & $(0.7)$ & $(0.7)$ & $(0.7)$ & $5.53^{* \star}$ & $4.33^{\star \star}$ & $8.61^{* *}$ & $6.23^{* *}$ \\
\hline & [2.7] & [2] & [2.7] & [2] & & & & \\
\hline Avg. NP worry * \# network partners & & & & & ** & NS & NS & $\star \star$ \\
\hline
\end{tabular}


Demographic Research - Special Collection 1: Article 9

-- Social Interactions and HIV/AIDS in Rural Africa --

\begin{tabular}{|c|c|c|c|c|c|c|c|c|}
\hline & \multicolumn{4}{|c|}{ Frequencies } & \multicolumn{4}{|c|}{ Relationship w/ worry $^{1}$} \\
\hline & \multicolumn{2}{|c|}{ Women } & \multicolumn{2}{|c|}{ Men } & \multicolumn{2}{|c|}{ Women } & \multicolumn{2}{|c|}{ Men } \\
\hline & 1998 & 2001 & 1998 & 2001 & 1998 & 2001 & 1998 & 2001 \\
\hline & $\mathrm{N}=878$ & $\mathrm{~N}=878$ & $\mathrm{~N}=660$ & $\mathrm{~N}=660$ & $\mathrm{~N}=878$ & $\mathrm{~N}=878$ & $\mathrm{~N}=660$ & $\mathrm{~N}=660$ \\
\hline \multicolumn{9}{|l|}{ COMMUNITY MARKERS } \\
\hline Religion ab wxyz & & & & & ** & NS & ** & ** \\
\hline Catholic & $19 \%$ & $18 \%$ & $18 \%$ & $18 \%$ & NS & NS & NS & NS \\
\hline Protestant/Revivalist/Traditional & $63 \%$ & $63 \%$ & $61 \%$ & $60 \%$ & - & - & - & - \\
\hline Muslim & $18 \%$ & $18 \%$ & $20 \%$ & $20 \%$ & $8.64^{\star *}$ & NS & $18.66^{\star *}$ & $2.12^{\star *}$ \\
\hline None & $0 \%$ & $0 \%$ & $2 \%$ & $2 \%$ & NS & NS & NS & $0.52+$ \\
\hline Last time attended a religious ceremony ${ }^{\mathrm{bx}}$ & & & & & & * & & NS \\
\hline In the last week & & $63 \%$ & & $68 \%$ & & - & & - \\
\hline In the last month & & $30 \%$ & & $22 \%$ & & $1.35^{\star}$ & & NS \\
\hline Last 2-6 months & & $4 \%$ & & $5 \%$ & & NS & & NS \\
\hline$>6$ months/Never & & $4 \%$ & & $6 \%$ & & $1.98^{*}$ & & NS \\
\hline Ethnicity ${ }^{x y z}$ & & & & & ** & ** & ** & ** \\
\hline Yao & $18 \%$ & $18 \%$ & $21 \%$ & $20 \%$ & $15.05^{* *}$ & $1.42+$ & $31.79^{\star *}$ & $4.97^{\star *}$ \\
\hline Chewa & $35 \%$ & $35 \%$ & $35 \%$ & $36 \%$ & - & - & - & - \\
\hline Lomwe & $4 \%$ & $4 \%$ & $5 \%$ & $5 \%$ & $48.92^{* *}$ & NS & $25.07^{\star *}$ & $2.81^{\star *}$ \\
\hline Tumbuka & $32 \%$ & $31 \%$ & $26 \%$ & $26 \%$ & $2.49^{\star \star}$ & $2.03^{* *}$ & $2.53^{* *}$ & $4.34^{* *}$ \\
\hline Ngoni & $5 \%$ & $5 \%$ & $7 \%$ & $7 \%$ & $3.34^{* *}$ & NS & $2.93^{* *}$ & $2.18^{* *}$ \\
\hline Senga & $3 \%$ & $4 \%$ & $2 \%$ & $3 \%$ & NS & NS & NS & $2.04^{*}$ \\
\hline Other & $4 \%$ & $3 \%$ & $4 \%$ & $3 \%$ & $4.29^{\star *}$ & $2.78^{* *}$ & $5.80^{* *}$ & NS \\
\hline Region ${ }^{x y z}$ & & & & & ** & $* *$ & ** & $\star *$ \\
\hline South (Balaka) & $27 \%$ & $27 \%$ & $29 \%$ & $29 \%$ & $22.82^{* *}$ & $1.32+$ & $30.68^{* *}$ & $3.56^{* *}$ \\
\hline Center (Mchinji) & $40 \%$ & $40 \%$ & $42 \%$ & $42 \%$ & - & - & - & \\
\hline North (Rumphi) & $33 \%$ & $33 \%$ & $29 \%$ & $29 \%$ & $2.62^{\star *}$ & $1.96^{* *}$ & $2.35^{\star *}$ & $3.85^{\star *}$ \\
\hline \multicolumn{9}{|l|}{ DEMOGRAPHIC CONTROLS } \\
\hline & 30.5 & 33.6 & 36.3 & 40.1 & & & & \\
\hline Age ${ }^{\text {abcd z }}$ & $(8.7)$ & $(8.9)$ & $(10.2)$ & $(10.4)$ & $1.02^{*}$ & NS & $1.02^{*}$ & NS \\
\hline & [29] & [32] & {$[35]$} & [38] & & & & \\
\hline Education ${ }^{\text {cd wy }}$ & & & & & NS & + & $* *$ & NS \\
\hline None & $33 \%$ & $30 \%$ & $20 \%$ & $17 \%$ & - & - & - & - \\
\hline Primary & $62 \%$ & $63 \%$ & $65 \%$ & $69 \%$ & NS & $1.39^{*}$ & $0.40^{* *}$ & NS \\
\hline Secondary+ & $6 \%$ & $7 \%$ & $14 \%$ & $14 \%$ & NS & NS & $0.46^{*}$ & NS \\
\hline & 5.2 & 5.3 & 5.0 & 5.2 & & & & \\
\hline Index of household wealth & $(4.1)$ & (3.6) & $(3.5)$ & $(3.1)$ & NS & NS & $0.96+$ & NS \\
\hline & [4.8] & [4.7] & [4.4] & {$[4.1]$} & & & & \\
\hline
\end{tabular}

Notes:

For interval- and ratio-level variables, entries in frequencies column are mean, (standard deviation), and [median].

Overall significance of polytomous categorical variables indicated in first line of variable results.

NS not significant; + significant at $\mathrm{p}<10 \%$; ${ }^{*}$ significant at $\mathrm{p}<5 \%$; ${ }^{*}$ significant at $\mathrm{p}<1 \%$.

${ }^{1}$ Results of ordered logistic regressions with worry. Figures presented are odds ratios. Robust standard errors used to calculate $\mathrm{p}-$ values.

${ }^{a}$ Significant $(p<5 \%)$ difference between frequencies for women and men in 1998. Results from $\chi^{2}$ test (likelihood ratio or Fischer exact) or t-tests on the equality of means or proportions, depending on the type of variable.

${ }^{b}$ Significant $(p<5 \%)$ difference between frequencies for women and men in 2001 . Results from $\chi^{2}$ test (likelihood ratio or Fischer exact) or t-tests on the equality of means or proportions, depending on the type of variable.

${ }^{c}$ Significant $(p<5 \%)$ difference between frequencies for men in 1998 and 2001 . Results from $\chi^{2}$ test (likelihood ratio or Fischer exact) or t-tests on the equality of means or proportions, depending on the type of variable.

${ }^{d}$ Significant $(p<5 \%)$ difference between frequencies for women in 1998 and 2001 . Results from $\chi^{2}$ test (likelihood ratio or Fischer exact) or t-tests on the equality of means or proportions, depending on the type of variable.

${ }^{w}$ Significant $(p<5 \%)$ difference between women and men in effect on worry in 1998.

${ }^{x}$ Significant $(p<5 \%)$ difference between women and men in effect on worry in 2001.

${ }^{y}$ Significant $(p<5 \%)$ difference between men in 1998 and 2001 in effect on worry.

${ }^{z}$ Significant $(p<5 \%)$ difference between women in 1998 and 2001 in effect on worry. 
Individual factors. The percentage of respondents that report having had extramarital sex did not change significantly from one wave to the next. Men's greater reporting of infidelity is consistent with the literature's contention that in sub-Saharan Africa, men are the more promiscuous sex (e.g., McGrath et al. 1993, Ray, Gumbo, and Mbizvo 1996). However, given the illicit nature of infidelity, both men and women likely underreported their extramarital sexual activity. As evidence of this possibility, on average $2.5 \%$ of female and $10.5 \%$ of male respondents report having engaged in extramarital sex in the past year, but a comparatively whopping $18 \%$ and $26 \%$, respectively, say their best friends have. The large discrepancy between these two sets of figures casts doubt on the veracity of respondents' reporting of sexual partnerships, especially their own.

Basic knowledge about HIV/AIDS, as indicated by the question about knowing a person's sero-status from her appearance, is high and perhaps saturated given the lack of change from one wave to the next. People are aware of the presence of HIV/AIDS in their community, as indicated by the preponderance that attribute thinness followed by death to HIV/AIDS. A majority of both men and women mistakenly believe that a single act of unprotected sex with an infected person is certain to give you HIV. Reporting that sex once with an infected person is not guaranteed to give you HIV is positively associated with worrying about HIV/AIDS for men, negatively associated for women. Respondents have attended a large number of funerals in the past month, but the specific number is irrelevant to how much they worry about HIV/AIDS. Given that on average, the number of funerals attended in the past month barely differs from the lifetime number of acquaintances whom respondents suspect died of AIDS, a possible explanation is that most deaths are not attributed to AIDS.

Social factors. Over half of women are older or approximately the same age as their husbands, although the magnitude of the difference in spouses' ages is not related to worry about HIV/AIDS for either sex. A large proportion of women earn an income, but earning an income is not associated with worry. Most respondents are married, and the percent married changes little from one wave to the next. However, this aggregate stasis disguises more extensive marital change at the individual level. Based on retrospective marital histories collected in 2001 and cross-checked against 1998 data, $14 \%$ of women and $18 \%$ of men experienced at least one marital dissolution or creation between waves. The number of times respondents have been married is significantly related to their worry about HIV/AIDS. Fewer men than women suspect their spouses of infidelity. However, the difference may partially be due to differential reporting, as men may feel greater pressure to say that their wives are faithful (Note 10). Approval of using condoms with a spouse doubled between waves for both sexes.

The mean number of people rural Malawians report chatting with about HIV/AIDS increased over time, suggesting that HIV/AIDS is still very much a topic of 
conversation. Men report having spoken with slightly more people about HIV/AIDS than women, and they have slightly more network partners in the first wave. The number of network partners total that a person has does not significantly impact his worry, but the number that are worried do. Similarly, if none of a respondent's conversational partners worry about HIV/AIDS, then she, too, is less likely to worry. Although women worry more about HIV/AIDS than do men, the two sexes' network partners worry about the same amount according to the various measures. Just as respondent worry declined for both men and women over time, so too did networkpartner worry despite an overall increase in the number of partners in respondents' conversational networks.

Community markers serve as indicators of extended social networks, as well as social environments that might impact experiences with HIV/AIDS. Men report being slightly more religious than women, as measured by their attendance at religious services. However, religiosity does not appear to be strongly associated with worry. What relationship does exist suggests that women who are highly religious worry less about HIV/AIDS.

\subsection{Multivariate results}

The results of the multivariate models are presented in Tables 3 through 6 . Each multivariate model consists of four regressions. The first is worry on individual factors and controls only. The second is worry on individual factors, controls, and social variables minus the network variables and region of residence. The third is worry on individual factors and controls, plus all social variables except region. The final model differs from the third in its inclusion of region. I split up the models with social variables in this fashion in order to distinguish between the effects of social networks and region on the other variables in the model. In the tables, the overall significance of polytomous categorical variables--tests of the null hypothesis that all the dummy coefficients are equal to zero--is indicated in the first line of variable results. 
Demographic Research - Special Collection 1: Article 9

-- Social Interactions and HIV/AIDS in Rural Africa --

Table 3: $\quad$ Multivariate Model, Ordered Logistic Regression of Worry on Individual and Social Variables, Odds Ratios, Women, 1998

\begin{tabular}{|c|c|c|c|c|}
\hline & $\begin{array}{l}\text { Individual } \\
\text { factors \& } \\
\text { controls }\end{array}$ & $\begin{array}{l}\text { + Social } \\
\text { factors }\end{array}$ & $\begin{array}{l}\text { + Network } \\
\text { variables }\end{array}$ & + Region \\
\hline Had extramarital sex in past year & $2.797+$ & $3.491^{*}$ & $6.316^{\star \star}$ & $5.523^{*}$ \\
\hline Ever used condoms & 0.776 & 0.579 & $0.395^{\star}$ & $0.422+$ \\
\hline Husband stays in wife's village & $0.443^{\star *}$ & 0.673 & $0.606+$ & 0.716 \\
\hline Knows cannot tell HIV status by how someone & $0.490^{*}$ & 0.803 & 0.784 & 0.828 \\
\hline \# sources of HIV/AIDS information exposed to & $1.666^{\star *}$ & $1.395^{\star \star}$ & $1.264+$ & 1.223 \\
\hline \# suspected to have died of AIDS & + & NS & NS & NS \\
\hline 0 & 1.037 & 1.051 & 1.754 & 1.652 \\
\hline $1-5$ & 1.002 & 0.974 & 1.399 & 1.297 \\
\hline $6-15$ & 1.316 & 1.009 & 1.145 & 0.996 \\
\hline $16+$ & - & - & - & - \\
\hline Don't know & $5.223^{\star}$ & $3.592^{*}$ & 3.859 & 2.865 \\
\hline Age & 1.011 & 1.006 & 0.998 & 0.997 \\
\hline Education & ** & NS & NS & NS \\
\hline None & - & - & - & - \\
\hline Primary & 0.893 & 1.321 & 1.170 & 1.264 \\
\hline Secondary+ & 0.866 & 1.094 & 0.876 & 1.064 \\
\hline Index of household wealth & 0.991 & 0.987 & 1.010 & 1.009 \\
\hline Marital status & & NS & NS & NS \\
\hline Not married & & 1.036 & 0.780 & 0.813 \\
\hline Monogamous union & & - & - & - \\
\hline Polygynous union & & 1.336 & 1.386 & 1.436 \\
\hline Opinion of fidelity of spouse & & ** & $\star \star *$ & ** \\
\hline Unfaithful/suspects unfaithful & & $2.514^{\star \star}$ & $2.826^{\star \star}$ & $3.112^{\star *}$ \\
\hline Can't/don't know & & $1.649^{*}$ & $1.702^{*}$ & $1.684^{\star}$ \\
\hline Probably faithful & & - & - & - \\
\hline Says OK to use condom w/ spouse & & 1.289 & 1.287 & 1.134 \\
\hline Religion & & ** & NS & NS \\
\hline Catholic & & $1.396+$ & 1.296 & 1.207 \\
\hline Protestant/Revivalist/Traditional & & - & - & - \\
\hline Muslim & & $2.908^{* *}$ & 1.937 & 0.763 \\
\hline None & & $0.232+$ & 0.350 & 0.374 \\
\hline Tribe & & ** & ** & NS \\
\hline Yao & & $7.010^{\star \star}$ & $3.967^{\star *}$ & 1.135 \\
\hline Chewa & & - & - & - \\
\hline Lomwe & & $39.180^{\star *}$ & $24.014^{\star \star}$ & $8.239^{*}$ \\
\hline Tumbuka & & $2.382^{\star \star}$ & $2.070^{* *}$ & 0.958 \\
\hline Ngoni & & $3.197^{\star \star}$ & 1.953 & 1.172 \\
\hline Senga & & 1.385 & 1.297 & 1.299 \\
\hline Other & & $3.707^{\star}$ & $2.281+$ & 0.914 \\
\hline \# chatted with about HIV/AIDS & & & 1.002 & 1.002 \\
\hline Average network partner (NP) worry & & & $2.368^{\star \star}$ & $2.261^{\star \star}$ \\
\hline \# network partners & & & $0.584^{*}$ & $0.614^{*}$ \\
\hline Average NP worry * \# NPs & & & $1.258^{*}$ & $1.241^{*}$ \\
\hline Region & & & & * \\
\hline South (Balaka) & & & & $10.851^{* *}$ \\
\hline Center (Mchinji) & & & & - \\
\hline North (Rumphi) & & & & 2.329 \\
\hline Observations & 878 & 878 & 878 & 878 \\
\hline Pseudo $R^{2}$ & 0.042 & 0.143 & 0.253 & 0.264 \\
\hline
\end{tabular}

Notes:

Robust standard errors used to calculate $p$-values.

Overall significance of polytomous categorical variables indicated in first line of variable results, with "NS" signifying "not significant." + significant at $\mathrm{p}<10 \%$; ${ }^{*}$ significant at $\mathrm{p}<5 \%$; ${ }^{* *}$ significant at $\mathrm{p}<1 \%$.

Italics indicate an interaction. 
Demographic Research - Special Collection 1: Article 9

-- Social Interactions and HIV/AIDS in Rural Africa --

Table 4: $\quad$ Multivariate Model, Ordered Logistic Regression of Worry on Individual and Social Variables, Odds Ratios, Women, 2001

\begin{tabular}{|c|c|c|c|c|}
\hline & $\begin{array}{l}\text { Individual } \\
\text { factors \& } \\
\text { controls }\end{array}$ & $\begin{array}{l}\text { + Social } \\
\text { factors }\end{array}$ & $\begin{array}{l}\text { + Network } \\
\text { variables }\end{array}$ & + Region \\
\hline Had extramarital sex in past year & 0.998 & 0.955 & 0.867 & 0.879 \\
\hline Ever used condoms & $1.495+$ & 1.354 & 1.124 & 1.121 \\
\hline Husband stays in wife's village & 1.142 & 1.252 & 1.047 & 1.050 \\
\hline Knows cannot tell HIV status by how someone looks & 0.689 & 0.691 & 0.715 & 0.717 \\
\hline \# sources of HIV/AIDS information exposed to & $1.324^{*}$ & $1.354^{*}$ & 1.052 & 1.053 \\
\hline \# suspected to have died of AIDS & NS & NS & NS & + \\
\hline 0 & 1.140 & 0.717 & 0.844 & 0.853 \\
\hline $1-5$ & 1.061 & 0.982 & $1.613+$ & $1.615+$ \\
\hline $6-15$ & 1.100 & 1.074 & $1.653+$ & $1.655+$ \\
\hline $16+$ & - & - & - & - \\
\hline Don't know & 2.785 & 3.299 & $7.139^{*}$ & $7.192^{*}$ \\
\hline Age & 1.002 & 0.995 & 0.992 & 0.991 \\
\hline Education & NS & NS & NS & NS \\
\hline None & - & - & - & - \\
\hline Primary & $1.352+$ & 1.157 & 0.873 & 0.863 \\
\hline Secondary+ & 1.285 & 0.960 & 0.898 & 0.889 \\
\hline Index of household wealth & 1.001 & 0.972 & 0.979 & 0.977 \\
\hline Marital status & & ** & ** & $\star \star$ \\
\hline Not married & & 0.777 & 0.830 & 0.830 \\
\hline Monogamous union & & - & - & - \\
\hline Polygynous union & & $1.943^{\star *}$ & $2.150^{\star *}$ & $2.146^{\star *}$ \\
\hline Opinion of fidelity of spouse & & ** & ** & ** \\
\hline Unfaithful/suspects unfaithful & & $2.509^{* *}$ & $2.691^{* *}$ & $2.703^{* *}$ \\
\hline Can't/don't know & & $2.467^{\star *}$ & $3.032^{* *}$ & $3.040^{\star *}$ \\
\hline Probably faithful & & - & - & - \\
\hline Says OK to use condom w/ spouse & & $2.074^{* *}$ & $1.971^{* *}$ & $1.984^{* *}$ \\
\hline Religion & & NS & + & NS \\
\hline Catholic & & 0.863 & 0.765 & 0.780 \\
\hline Protestant/Revivalist/Traditional & & - & - & - \\
\hline Muslim & & 1.655 & 1.652 & 1.680 \\
\hline None & & 0.264 & 0.282 & 0.226 \\
\hline Tribe & & ** & $* *$ & NS \\
\hline Yao & & 0.900 & 0.685 & 0.677 \\
\hline Chewa & & - & - & - \\
\hline Lomwe & & 0.815 & 0.748 & 0.747 \\
\hline Tumbuka & & $2.258^{\star *}$ & $3.044^{* *}$ & $2.389^{*}$ \\
\hline Ngoni & & 1.313 & $1.501+$ & 1.372 \\
\hline Senga & & 1.249 & 1.207 & 1.192 \\
\hline Other & & $3.043^{* *}$ & $2.608^{*}$ & $2.354+$ \\
\hline \# chatted with about HIV/AIDS & & & $1.030+$ & $1.030+$ \\
\hline Average network-partner worry & & & $5.311^{* *}$ & $5.297^{\star *}$ \\
\hline \# network partners & & & 1.137 & 1.141 \\
\hline Region & & & & NS \\
\hline South (Balaka) & & & & 0.997 \\
\hline Center (Mchinji) & & & & - \\
\hline North (Rumphi) & & & & 1.293 \\
\hline Observations & 878 & 878 & 878 & 878 \\
\hline Pseudo $\mathrm{R}^{2}$ & 0.012 & 0.070 & 0.187 & 0.187 \\
\hline
\end{tabular}

Notes:

Robust standard errors used to calculate p-values.

Overall significance of polytomous categorical variables indicated in first line of variable results, with "NS" signifying "not significant." + significant at $p<10 \%$; ${ }^{*}$ significant at $p<5 \%$; ${ }^{* *}$ significant at $p<1 \%$. 
Demographic Research - Special Collection 1: Article 9

-- Social Interactions and HIV/AIDS in Rural Africa --

Table 5: $\quad$ Multivariate Model, Ordered Logistic Regression of Worry on Individual and Social Variables, Odds Ratios, Men, 1998

\begin{tabular}{|c|c|c|c|c|}
\hline & $\begin{array}{l}\text { Individual } \\
\text { factors \& } \\
\text { controls }\end{array}$ & $\begin{array}{l}\text { + Social } \\
\text { factors }\end{array}$ & $\begin{array}{l}\text { + Network } \\
\text { variables }\end{array}$ & + Region \\
\hline Had extramarital sex in past year & 1.091 & 1.067 & 1.187 & 1.222 \\
\hline Ever used condoms & $1.664^{*}$ & 1.455 & $1.883^{*}$ & $1.824^{*}$ \\
\hline Husband stays in wife's village & $0.350^{*}$ & 1.003 & 1.167 & 1.264 \\
\hline Knows cannot tell HIV status by how someone looks & $0.398^{*}$ & 0.776 & 0.783 & 0.800 \\
\hline \# sources of HIV/AIDS information exposed to & $1.312^{*}$ & $1.328^{*}$ & $1.310+$ & 1.280 \\
\hline \# suspected to have died of AIDS & * & NS & * & NS \\
\hline 0 & $3.692^{*}$ & 1.955 & $3.702^{* *}$ & $3.159^{* *}$ \\
\hline $1-5$ & 1.224 & 0.988 & 1.273 & 1.174 \\
\hline $6-15$ & $1.610^{*}$ & 1.273 & 1.536 & 1.415 \\
\hline $16+$ & - & - & - & \\
\hline Don't know & $3.426+$ & 1.704 & 2.988 & 2.260 \\
\hline Age & $1.020^{*}$ & 0.998 & 0.995 & 0.993 \\
\hline Education & ** & NS & NS & NS \\
\hline None & - & - & - & - \\
\hline Primary & $0.442^{\star \star}$ & 0.865 & 0.983 & 0.952 \\
\hline Secondary+ & $0.571+$ & 1.266 & 1.364 & 1.355 \\
\hline Index of household wealth & $0.947^{*}$ & 0.961 & 0.957 & 0.959 \\
\hline Marital status & & NS & NS & NS \\
\hline Not married & & 1.769 & 1.061 & 0.966 \\
\hline Monogamous union & & - & - & - \\
\hline Polygynous union & & 1.209 & $1.737+$ & $1.748+$ \\
\hline Opinion of fidelity of spouse & & * & ** & $* *$ \\
\hline Unfaithful/suspects unfaithful & & $3.048^{* *}$ & $2.667^{*}$ & $2.818^{*}$ \\
\hline Can't/don't know & & 1.372 & $1.862^{*}$ & $1.778^{*}$ \\
\hline Probably faithful & & - & - & - \\
\hline Says OK to use condom w/ spouse & & 1.168 & 1.252 & 1.241 \\
\hline Religion & & * & NS & NS \\
\hline Catholic & & 0.931 & 1.146 & 1.072 \\
\hline Protestant/Revivalist/Traditional & & - & - & - \\
\hline Muslim & & $6.738^{* *}$ & 5.019 & 3.358 \\
\hline None & & 1.381 & 0.582 & 0.621 \\
\hline Tribe & & ** & ** & * \\
\hline Yao & & $5.394^{* *}$ & 1.868 & 0.742 \\
\hline Chewa & & - & - & - \\
\hline Lomwe & & $29.482^{\star \star}$ & $11.014^{\star *}$ & $4.212^{*}$ \\
\hline Tumbuka & & $2.262^{\star \star}$ & $1.656^{*}$ & 0.992 \\
\hline Ngoni & & $3.162^{* *}$ & $2.598^{* *}$ & $2.096^{*}$ \\
\hline Senga & & 1.829 & 1.964 & 2.001 \\
\hline Other & & $4.565^{* *}$ & $2.168+$ & 1.000 \\
\hline \# chatted with about HIV/AIDS & & & 0.997 & 0.997 \\
\hline Average network-partner worry & & & $6.819^{* *}$ & $6.405^{\star *}$ \\
\hline \# network partners & & & 0.969 & 0.973 \\
\hline Region & & & & NS \\
\hline South (Balaka) & & & & $4.351+$ \\
\hline Center (Mchinji) & & & & - \\
\hline North (Rumphi) & & & & 1.801 \\
\hline Observations & 660 & 660 & 660 & 660 \\
\hline Pseudo $\mathrm{R}^{2}$ & 0.050 & 0.178 & 0.328 & 0.334 \\
\hline
\end{tabular}

Notes:

Robust standard errors used to calculate $p$-values.

Overall significance of polytomous categorical variables indicated in first line of variable results, with "NS" signifying "not significant."

+ significant at $\mathrm{p}<10 \%$; ${ }^{*}$ significant at $\mathrm{p}<5 \%$; ${ }^{* *}$ significant at $\mathrm{p}<1 \%$. 
Demographic Research - Special Collection 1: Article 9

-- Social Interactions and HIV/AIDS in Rural Africa --

Table 6: $\quad$ Multivariate Model, Ordered Logistic Regression of Worry on Individual and Social Variables, Odds Ratios, Men, 2001

\begin{tabular}{|c|c|c|c|c|}
\hline & $\begin{array}{l}\text { Individual } \\
\text { factors \& } \\
\text { controls }\end{array}$ & $\begin{array}{l}\text { + Social } \\
\text { factors }\end{array}$ & $\begin{array}{l}\text { + Network } \\
\text { variables }\end{array}$ & + Region \\
\hline Had extramarital sex in past year & $2.173^{\star *}$ & $2.320^{* *}$ & $2.139^{*}$ & $2.219^{*}$ \\
\hline Ever used condoms & 1.183 & 0.962 & 0.862 & 0.859 \\
\hline Husband stays in wife's village & 0.645 & 0.723 & $0.434+$ & 0.452 \\
\hline Knows cannot tell HIV status by how someone & 1.352 & 1.485 & 1.420 & 1.420 \\
\hline \# sources of HIV/AIDS information exposed to & $1.384^{*}$ & $1.350^{*}$ & 1.237 & 1.245 \\
\hline \# suspected to have died of AIDS & NS & NS & NS & NS \\
\hline 0 & 1.763 & 1.028 & 1.021 & 1.049 \\
\hline $1-5$ & 1.178 & 0.782 & 0.819 & 0.831 \\
\hline $6-15$ & 1.141 & 1.040 & 1.138 & 1.118 \\
\hline $16+$ & - & - & - & - \\
\hline Don't know & 1.650 & 1.081 & 2.868 & 2.986 \\
\hline Age & $1.018^{*}$ & 1.008 & 1.003 & 1.002 \\
\hline Education & NS & NS & NS & NS \\
\hline None & - & - & - & - \\
\hline Primary & 1.005 & 1.153 & 1.093 & 1.025 \\
\hline Secondary+ & 0.820 & 0.695 & 0.637 & 0.565 \\
\hline Index of household wealth & 0.999 & 0.980 & 0.989 & 0.982 \\
\hline Marital status & & NS & * & * \\
\hline Not married & & $0.318+$ & 0.460 & 0.468 \\
\hline Monogamous union & & - & - & - \\
\hline Polygynous union & & 0.949 & $1.622^{*}$ & $1.662^{*}$ \\
\hline Opinion of fidelity of spouse & & 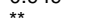 & NS & + \\
\hline Unfaithful/suspects unfaithful & & $2.307^{*}$ & 1.790 & 1.788 \\
\hline Can't/don't know & & $1.482^{*}$ & $1.360_{+}$ & $1.390_{+}$ \\
\hline Probably faithful & & - & - & - \\
\hline Says OK to use condom w/ spouse & & 1.368 & 1.170 & 1.159 \\
\hline Religion & & NS & NS & NS \\
\hline Catholic & & 0.774 & 0.788 & 0.864 \\
\hline Protestant/Revivalist/Traditional & & - & - & - \\
\hline Muslim & & 0.514 & 0.215 & 0.315 \\
\hline None & & 0.698 & 0.709 & 0.732 \\
\hline Tribe & & $* *$ & $\star \star$ & NS \\
\hline Yao & & $9.168^{* *}$ & $10.737^{*}$ & $8.071+$ \\
\hline Chewa & & - & - & - \\
\hline Lomwe & & $2.674^{*}$ & 1.768 & 2.016 \\
\hline Tumbuka & & $5.208^{\star *}$ & $4.830^{* *}$ & 1.490 \\
\hline Ngoni & & $2.447^{\star *}$ & $3.247^{* *}$ & $2.550^{*}$ \\
\hline Senga & & $2.299+$ & 1.624 & 1.604 \\
\hline Other & & 2.137 & 2.250 & 1.103 \\
\hline \# chatted with about HIV/AIDS & & & 0.989 & 0.989 \\
\hline Average network partner (NP) worry & & & 0.509 & 0.502 \\
\hline \# network partners & & & $0.269^{* *}$ & $0.264^{\star *}$ \\
\hline Average NP worry * \# NPs & & & $2.057^{* *}$ & $2.088^{* *}$ \\
\hline Region & & & & * \\
\hline South (Balaka) & & & & 0.901 \\
\hline Center (Mchinji) & & & & - \\
\hline North (Rumphi) & & & & $3.643^{*}$ \\
\hline Observations & 660 & 660 & 660 & 660 \\
\hline Pseudo $R^{2}$ & 0.018 & 0.090 & 0.247 & 0.254 \\
\hline
\end{tabular}

Notes:

Robust standard errors used to calculate $p$-values.

Overall significance of polytomous categorical variables indicated in first line of variable results, with "NS" signifying "not significant." + significant at $\mathrm{p}<10 \%$; ${ }^{*}$ significant at $\mathrm{p}<5 \%$; ${ }^{* \star}$ significant at $\mathrm{p}<1 \%$.

Italics indicate an interaction. 
Looking at the results for the first set of models, which have only individual and control variables, we see that certain individual factors are significantly related to worry. The following variables are significant in at least one model: having engaged in extramarital sex, having used condoms, where the husband usually stays, receiving information about HIV/AIDS from multiple sources, the number of acquaintances that died of AIDS, age, education, and wealth. To highlight a few of these relationships, in some of the models, respondents who report having had extramarital sex in the past year worry more about HIV/AIDS. The relationship between condom use and worry is positive, suggesting that worry prompts condom use rather than the reverse, as the model specifies. Knowing that you cannot tell someone's sero-status by their appearance decreases worry, but having been exposed to information about HIV/AIDS from multiple sources increases it. For men in 1998, knowing many people who died of AIDS is associated with reduced rather than increased levels of worry, an unexpected finding replicated by a Ugandan study that found that if a person knew more than 15 suspected AIDS victims, he was more likely than if he knew fewer to say that he was certain he was HIV negative (Ntozi and Kirunga 1997). For men, age is positively associated with worry (Note 11). Education is negatively associated with men's worry, but positively associated with women's.

When the social variables minus the network variables and region are added to the models, a number of individual variables cease being significant. Education ceases to be significant in any model, as does condom use, the number suspected to have died of AIDS, the wealth index, and knowing that a healthy-looking person can have AIDS. Nonetheless, a few of the individual variables continue to be significant in some models, and the overall pattern remains largely intact; specifically, behavior, as indicated by having recently engaged in extramarital sex, and knowledge, as measured by exposure to different sources of "expert" information about HIV/AIDS, are still significantly related to respondent worry. In regards to social variables, especially for women, being in a polygynous marriage and suspecting your spouse of infidelity are associated with increased worry about HIV/AIDS. Research in Zimbabwe found that divorced and separated women were more likely than currently married women to feel at risk for contracting HIV/AIDS (Gregson et al. 1998), yet I find no consistent differences between monogamously married and single respondents. Ethnicity is significant in all of the models, and religious affiliation is significant in half. Specifically, Catholics are not significantly different from Protestants, Revivalists, and adherents to traditional religions, and Muslims worry more about HIV/AIDS than do Christians.

Adding the network-partner variables to the models has a mixed effect on the significance of the individual variables. Whereas the information variable drops out of two of the four models in which it was previously significant, condom use and where 
the husband usually stays become newly significant in two models. The extramarital sex variable appears to have the most tenacious effect on worry of any individual variable. Broadly speaking, the previously significant variables regarding one's spouse remain significant, as do ethnicity and region in some models. That the other significant variables remain largely unaffected suggests that while networks have a large, significant effect on worry, that effect is largely independent of the effects of the other variables in the models. In regards to the network effects themselves, as depicted in Figures 2 and 3 (Note 12), for women in 1998 and men in 2001, the relationship between respondent worry and the average level of worry in a respondent's network depends on the number of people in that network. Specifically, the more numerous the partners, the more closely the respondent's worry resembles that of his network partners.

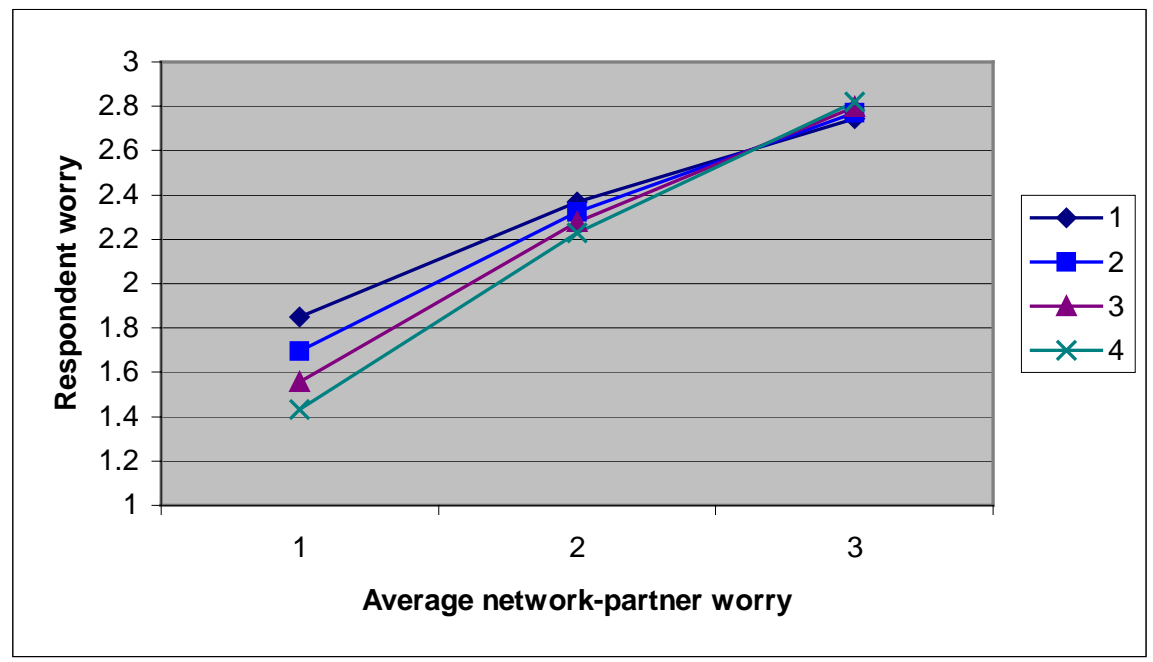

Figure 2: $\quad$ Effect of Number of Network Partners and Average Network-partner Worry on Respondent Worry about HIV/AIDS, Women, 1998

Note:

Worry ranges from 1 (not worried) to 3 (very worried). 


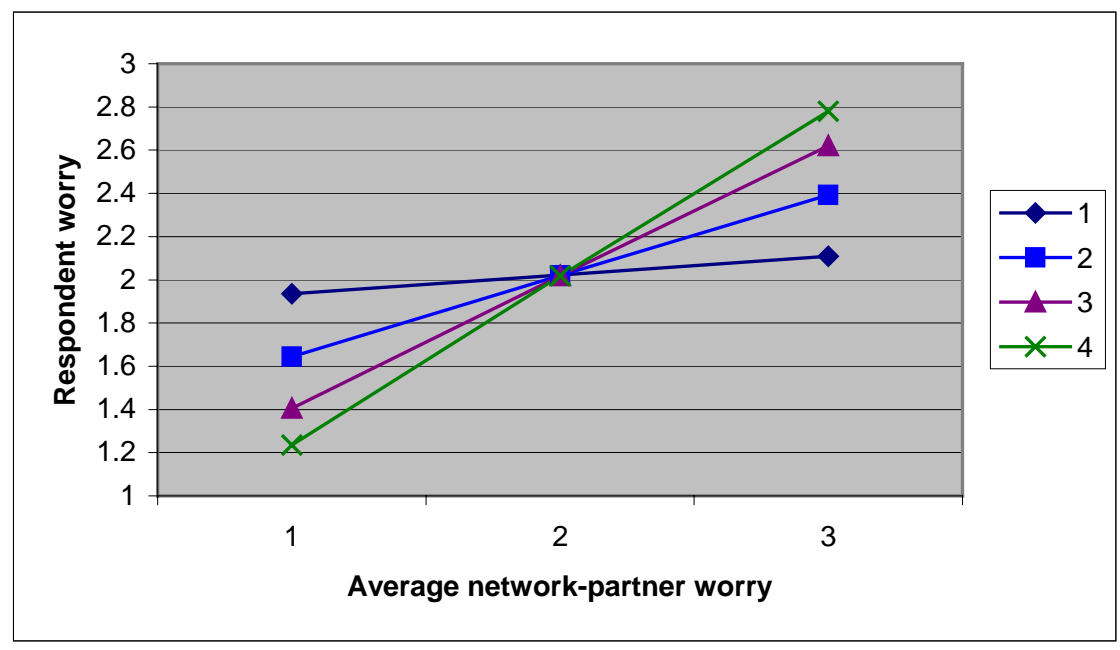

Figure 3: $\quad$ Effect of Number of Network Partners and Average Network-partner Worry on Respondent Worry about HIV/AIDS, Men, 2001

Note:

Worry ranges from 1 (not worried) to 3 (very worried).

Region of residence is highly correlated with ethnicity, and to a lesser extent, religious affiliation. Consequently, when we add region to the models, the biggest change is that ethnicity ceases to be significant in three of the four models. The individual variable, where the husband usually stays, becomes insignificant in the two models in which it was previously marginally significant. The network coefficients change little, however, suggesting that regional differences do not account for networks' strong effects on worry. The relationship between region and worry is curiously inconsistent across time and sex. Part of the explanation is divergent changes in regional levels of average worry from one wave to the next. As illustrated in Table 7, while worry in Balaka dropped precipitously for both sexes between 1998 and 2001, changes in worry in the other two regions were smaller and inconsistent across sexes. Once we control for social variables with which it is correlated, region has little explanatory power, as indicated by the minimal increases in the pseudo $\mathrm{R}^{2}$ values when we add it to the models. 
Demographic Research - Special Collection 1: Article 9

-- Social Interactions and HIV/AIDS in Rural Africa --

Table 7: $\quad$ Change in Average Level of Worry about HIV/AIDS by Region, Women and Men, 1998 and 2001

\begin{tabular}{lllll}
\hline & Women (N=878) & & \multicolumn{1}{l}{ Men (N=660) } & \% change to 2001 \\
\hline & $\mathbf{1 9 9 8}$ & \% change to 2001 & $\mathbf{1 9 9 8}$ & $-24.6 \%$ \\
\hline South (Balaka) & 2.90 & $-23.8 \%$ & 2.89 & $-12.6 \%$ \\
Center (Mchinji) & 2.09 & $+0.5 \%$ & 1.82 & $+0.5 \%$ \\
\hline North (Rumphi) & 2.50 & $-3.6 \%$ & 2.21 & +5 \\
\hline
\end{tabular}

Note:

Worry ranges from 1 (not worried) to 3 (very worried).

The most notable finding to emerge from the multivariate models containing all the variables, both individual and social, is the strong impact of network worry on respondent worry. Not only is the significance across all four models remarkable, so, too, are the large magnitudes of the effects. For example, according to the men's 1998 model, increasing average worry from not worried to moderately worried or from moderately worried to very worried increases by a factor of six the odds that a respondent is in a higher category of worry. Suspecting your spouse of infidelity also stands out for its large and robust impact on respondent worry. Compared to respondents who report that their spouses are probably faithful, those who suspect or know of infidelity are between 2.7 and 3.1 times (depending on the model) more likely to be in a higher category of worry. Respondents who "can't" or "don't" know if their spouses are faithful or who report that their spouses pose the greatest threat for transmitting HIV are between 1.4 and 3 times more worried about HIV/AIDS. It is also worth noting that suspected infidelity has a greater effect on women's than men's worry about HIV/AIDS, and more women than men doubt their spouses' fidelity.

The pseudo $\mathrm{R}^{2}$ statistic for ordered categories logistic regression is based on the difference in the log-likelihoods for the fitted model and a model with no explanatory variables (Allison 1999). While it cannot be interpreted as the proportion of variance explained by the independent variables the way an OLS $\mathrm{R}^{2}$ can, it can be loosely regarded as a measure of the extent to which a model's explanatory variables account for observed differences in the dependent variable. The $\mathrm{R}^{2}$ statistics for the models with only individual variables and controls range from 0.01 to 0.05 , suggesting that individual variables matter little when predicting respondents' worry about HIV/AIDS. The values for the models with social variables minus the network variables and region are at least three times as large as the $\mathrm{R}^{2}$ for the corresponding individual models. The $\mathrm{R}^{2}$ statistic for the full model with the lowest predictive value is almost four times the value for the individual model with the highest predictive value. Based on the substantially higher $\mathrm{R}^{2}$ statistics for the models with social variables and the finding that when I control for social variables in the models, individual variables are no longer 
significant, I conclude that social factors have a greater influence on worry about HIV/AIDS than do the individual factors included in this analysis. Variables related to one's spouse and network-partner worry have the greatest and most robust impact on respondent worry.

\section{Discussion}

Since it was learned that HIV/AIDS in sub-Saharan Africa is transmitted mostly through heterosexual sex, researchers and interventionists have focused on individuals under the assumption that, if Africans only had the necessary information and skills, they would change their behaviors. In recent years, the focus has gradually shifted to other, more macro-level factors like gender power imbalances, network influences, and poverty. I contribute to the debate over whether this change in focus is appropriate by evaluating the relative importance of individual versus social factors in contributing to rural Malawians' worry about HIV/AIDS.

The overriding message that emerges from this analysis is that individual characteristics and reported behaviors matter far less in determining worry about HIV/AIDS than how much respondents' conversational partners worry and whether they suspect their spouses of infidelity. This finding was remarkably consistent across time and sex. People's concern rubs off on their friends such that, regardless of whether or not a person is at risk of contracting HIV/AIDS, he is more likely to worry about the disease if his friends are worried. Alternatively, we might suppose that, given the uncertainty surrounding HIV/AIDS due to people's inability to tell if others-or they, themselves - are infected, individuals look to those around them for clues as to how they should feel and behave in the context of the epidemic. These clues may take the form of information, or they may come by way of example. Yet the concerns of those with whom a person regularly interacts are not the only factors that matter. Other social variables, including ethnicity, region, and variables concerning one's spouse, were also significantly related to respondent worry about AIDS. The individual variable that had the largest, most robust effect on worry is reported engagement in extramarital sex, which was positively associated with worry about HIV/AIDS. Yet caution is called for in drawing conclusions from this finding, as it may be subject to response bias. Given the illicit nature of infidelity, it is likely that respondents underreported their extramarital sex, as suggested by a study from Malawi that used biomarkers to validate reports of sexual activity (Taha et al. 1996). Studies that used informal, in-depth qualitative interviewing to investigate whether extramarital sex is underreported in the MDICP survey similarly concluded that infidelity is underreported, although it is difficult to quantify to what extent (Tawfik 2003, Behrman et al. 2003). 
Unfortunately, it is impossible to know whether respondents who admitted to having extramarital sex are representative of the average person with extramarital partners.

While these findings of large, robust effects of social variables on worry do not directly contradict the prevailing models of health behavior, which focus on individuals, they do complicate them in interesting ways. According to a UNAIDS review of theories of HIV/AIDS-related behavioral change, "Models of individual behavioral change... generally do not consider the interaction of social, cultural, and environmental issues as independent of individual factors" (UNAIDS 1999:6). One of the factors these theories do consider is perceived risk, which they treat as a determinant of behavior: "Although each theory is built on different assumptions they all state that behavioral changes occur by altering potential risk-producing situations and social relationships, risk perceptions, attitudes, self-efficacy beliefs, intentions and outcome expectations [emphasis added]" (UNAIDS 1999:6). Although the association between worry and perceived risk is imperfect, it is nonetheless strong. Consequently, my finding of a strong social basis for worry calls into question these models' omission of a social element. Other studies have similarly argued that theories of behavioral change that fail to consider network and peer effects are inadequate (e.g., Vandlandingham et al. 1995, UNAIDS 1999, Bunnell 1996). Thus, a more complete model of risk behavior must take into account the social underpinnings of worry.

Another interesting finding to emerge from this study is that worry declined between 1998 and 2001 for both sexes. Evidence from rural Kenya has documented a similar decline in that country (Watkins and Schatz 2001). The decline in worry evident in this study was not due to unobserved heterogeneity since the MDICP as analyzed is a longitudinal sample, so the same people were interviewed in both waves. It also cannot be attributed to an age effect, as what little association exists between worry and age is positive. That said, worry did not decline equally in all regions. In fact, women in the central region and men in the north became slightly more worried about HIV/AIDS over time. Additional research is needed to investigate why worry changed the way it did in the different regions.

Another finding worth noting is that many of the variables that influence people's levels of worry suggest a close correspondence between factors that epidemiologists believe put people at risk and factors that are locally deemed risky (e.g., engaging in extramarital sex, having an adulterous spouse). This correspondence may indicate that both groups have independently picked up on the same real-world phenomena. However, it could also reflect the possibility that respondents have absorbed educational messages (e.g., unprotected sex is dangerous) disseminated by HIV/AIDS prevention programs. Either way, this finding suggests that, if HIV/AIDS continues to spread in Malawi, it is not for lack of awareness of the relevant risk factors. Additional support for this conclusion is weakly (because it concerns data from another country) 
provided by a recent Ugandan study that found that determinants of perceived risk of HIV infection are also known risk factors for contracting HIV/AIDS. Moreover, patterns of sex-specific perceived risk mirror differences in actual sero-prevalence (Kengeya-Kayondo et al. 1999).

There are a number of limitations to this study. First, I conclude that, since few of the individual variables analyzed are significantly related to worry, and the models with individual variables only have low $\mathrm{R}^{2} \mathrm{~s}$, individual factors must not be important determinants of worry about HIV/AIDS. However, strictly speaking, this would only be the case if I had observations without measurement error for all the individual variables of interest. Of course, I have neither: there are many potentially important individual variables (e.g., risk aversion, tendency to discount the future) for which I have no data, and other variables for which I do have information may be measured poorly. The cross-sectional nature of the data as analyzed exacerbates the problem because the effects of potentially endogenous variables such as condom use, which may both affect and be affected by worry about infection, will be biased downwards. Moreover, even if social variables have as large an effect on worry as I suggest, the low $\mathrm{R}^{2} \mathrm{~s}$ for the models with social variables mean that individual factors may as yet have a sizeable, albeit unobserved, effect on worry.

Overall, it is important to emphasize that mine is not a direct test of the comparative validity of the different types of models. Such an analysis is beyond the scope of this article because I lack data on many of the relevant factors. Rather, this is a more general test of what constructs matters, and which matter more-individual, cognitive-behavioral factors, or social and environmental factors. The finding that social factors, and in particular, network factors predominate is less a negation of the validity of individual, psychosocial models than it is a demonstration of the importance of social and environmental factors operating independently of individual factors.

Another limitation of this study is that the generalizability of my findings to Malawi on the whole or to other populations in sub-Saharan Africa is questionable due to restrictions placed on the sample that render it potentially unrepresentative. These include limiting the original sample to ever-married women and their husbands, dropping respondents interviewed in one wave only, and dropping respondents who reported never having discussed AIDS with others or who were unable to report the level of worry of at least one conversant. While these restrictions may limit the generalizability of the conclusions to other populations within or outside Malawi, analyses conducted by the author (not shown) and by Bignami-Van Assche et al. (2003) suggest that they did not bias the results for the population studied.

A third limitation stems from my decision to use worry as a proxy for perceived risk. As noted, although they are similar, the two concepts are not identical. While the emotive component implicit in worry may be viewed as rendering it superior to 
perceived risk as a predictor of behavioral change, to the extent that predictors of worry are dissimilar from predictors of perceived risk as a result of this additional component, my conclusions regarding perceived risk - the concept explicitly referred to in most individual models of risk behavior--are invalid. For example, due to personality differences such as differential propensities for risk aversion, individuals with the same perceived risk of infection may express varying levels of worry about HIV/AIDS. Differential exposure to other stressors or ability to manage stress may produce a similar effect. Unobservables such as these, which are related to worry but not perceived risk, may introduce bias not accounted for in the present analysis. While one could argue that worry is interesting to investigate in its own right, this potential bias is problematic for my conclusions regarding the salience of social factors in predicting behavioral change within the framework of existing models of health behavior.

The final limitation has to do with the finding of strong network effects on respondent worry. The network questions were designed to gage how worried are the people with whom respondents discuss HIV/AIDS. If respondents projected their own concerns onto their network partners rather than accurately reporting their partners' feelings, they violated the basic premise of the exercise. Yet this is a real possibility, and to the extent that projected concern accounts for the observed association between respondent worry and network-partner worry, the results are biased. A second potential problem is that of network endogeneity: do people intentionally choose as network partners others who think or behave the way they do, or in this case, who worry about HIV/AIDS to the same extent that they do? Research on fertility networks indicates that respondents typically choose network partners based on similarities across a multitude of characteristics rather than just one (Warriner and Watkins 2000). Nevertheless, network endogeneity stemming from selectivity and unobserved heterogeneity is still a troubling possibility.

Caveats notwithstanding, an Australian study on the determinants of perceived risk found similar evidence of strong network effects, concluding "Perceived personal risk was influenced most by perceived risk to friends and to people with the same sexual practices" (Timmins et al. 1998). Providing further support, albeit indirect, numerous studies in sub-Saharan Africa have documented the successes of peer-led intervention programs (e.g., Mouli 1992, Williams and Ray 1993). My finding of a strong network effect on respondent worry may help account for these successes, as people who are worried about HIV/AIDS should be more willing to take precautions to protect themselves against infection. Lastly, mounting evidence from the family planning literature suggests that networks matter even after controlling for unobserved factors that may influence both the selection of partners and the adoption of contraception, lending credence to the independent effects of networks on behaviors (e.g., Montgomery, Casterline, and Heiland 2001, Behrman, Kohler, and Watkins 2002). An 
analysis that used fixed effects and instrumental variables to control for the possibility of non-random selection similarly found that effects of networks on worry about AIDS are robust to these controls (Kohler, Behrman, and Watkins 2002).

While the importance of social-structural variables to behavioral change has been demonstrated by past research, comparatively little attention has been focused on predictors of a critical component of health behavior, perceived risk. I contribute to the debate on the determinants of behavioral change by analyzing the relative importance of individual versus social factors in accounting for levels of worry in a high-prevalence

population in sub-Saharan Africa. As such, I find support for the increasingly popular notion that social influence must be incorporated into our understanding of how and why people change their behavior in response to HIV/AIDS.

\section{Acknowledgements}

This research was supported by NICHD training grant HD-07242 through the Population Studies Center, University of Pennsylvania. 


\section{Notes}

1. The AIDS Risk Reduction model also incorporates elements of Diffusion of Innovation theory (UNAIDS 1999).

2. Values for current perceived risk are answers to a question regarding the "likelihood or chance that [the respondent] is infected with HIV/AIDS now." Possible answers were "no likelihood," "low," "medium," "high," and "don't know." Respondents who did not answer "high" were then asked to evaluate the likelihood of future infection.

3. Survey questions were written in English and then translated into three local languages used to conduct the interviews: Chichewa, Yao, and Tumbuka.

4. To account for the likelihood that some respondents never used condoms because they perceive their risk of HIV infection to be negligible, I tested for interactions in the second wave between condom use and both current and cumulative risk. Because neither interaction was significantly related to worry, they were dropped from the model.

5. Unfortunately, because this question refers to the previous year, newlyweds may have included premarital partners in their answers.

6. Because so few respondents (four in total) reported that the risk of infection associated with a single episode of unprotected sex with an infected partner is zero, I combined the corresponding response category with the next lowest category, "low." The true likelihood of infection given one act of unprotected sex with an HIV-positive partner is less than $1 / 2$ of one percent (Bracher, Santow, and Watkins 2003).

7. Treating the number of funerals attended in the past month as indicative of perceived severity or prevalence of AIDS assumes that respondents attribute the majority of local deaths to AIDS, which qualitative data suggest they do.

8. My intent in including a variable for self-employment in the women's models is to assess whether the data support a hypothesis common in the literature rather than to promote that hypothesis or suggest that it is the only reason we should expect to find a relationship between women's paid work and worry about HIV/AIDS. It is equally plausible that women who work are compelled to do so because their husbands spend their earnings on girlfriends or are too ill to themselves work, yielding a positive association between women's employment and worry.

9. Answers of "don't know" were excluded from calculations. 
10. Studies (e.g., Njovana and Watts 1996) proclaim that while it is considered acceptable in sub-Saharan Africa for men to engage in extramarital sex, husbands are expected to divorce adulterous wives. Consequently, a man who stays with an unfaithful wife may feel pressured to lie about her infidelity.

11. An age-squared term used to test for nonlinear relationships between age and worry was not significant in any of the models, so it was dropped.

12. The graphs depict average predicted values calculated using the equation, $\log \left[\mathrm{F}_{\mathrm{ij}} /\left(1-\mathrm{F}_{\mathrm{ij}}\right)\right]=\alpha \mathrm{x}_{\mathrm{i} 1}+\beta \mathrm{x}_{\mathrm{i} 2}+\chi \mathrm{x}_{\mathrm{i} 3}$, where $\mathrm{x}_{\mathrm{i} 1}$ is average value of network-partner worry for individual $i, \mathrm{x}_{\mathrm{i} 2}$ is the number of AIDS network partners for individual $i$, $\mathrm{x}_{\mathrm{i} 3}$ is the value of the interaction term for individual $i$ (average worry * number of partners), and $\mathrm{F}_{\mathrm{ij}}$ is the probability that individual $i$ is in the $j$ th category or higher. 
Demographic Research - Special Collection 1: Article 9

-- Social Interactions and HIV/AIDS in Rural Africa --

\section{References}

Aggleton P, O’Reilly K, Slutkin G, Davies P. (1994). "Risking everything? Risk behavior, behavioral change, and AIDS." Science, New Series 265(5170):341345 .

Allison P. (1999). Logistic regression using the SAS system: Theory and Application. Cary, NC: SAS Institute.

Ajzen I, Fishbein M. (1980). Understanding attitudes and predicting social behavior. Englewood Cliffs, NJ: Prentice-Hall, Inc.

Auerbach J, Wypijewska C, Brodil K. (1994). AIDS and behavior: An integrated approach. Washington D.C.: National Academy Press.

Bandura A. (1977). Social Learning Theory, Englewood Cliffs, NJ: Prentice-Hall.

Becker MH, Ed. (1974). The Health Belief Model and Personal Health Behavior. Thorofare, NJ: Slack.

Behrman JR, Kohler H-P, Watkins SC (2002). "Social networks and changes in contraceptive use over time: evidence from a longitudinal study in rural Kenya." Demography 39(4):713-738.

Bignami-Van Assche S, Reniers G, Weinreb A (2003). "An Assessment of the KDICP and MDICP Data Quality". Demographic Research - Special Collection 1: "Social Interactions and HIV/AIDS in Rural Africa", edited by Susan Watkins, Eliya M. Zulu, Jere Behrman, and Hans-Peter Kohler. http://www.demographicresearch.org

Bracher M, Santow G, Watkins SC (2003). "Moving and marrying" Demographic Research - Special Collection 1: "Social Interactions and HIV/AIDS in Rural Africa", edited by Susan Watkins, Eliya M. Zulu, Jere Behrman, and Hans-Peter Kohler. http://www.demographic-research.org

Bunnell R (1996). "Promoting or paralyzing behavioral change: understanding gender and high levels of perceived risk of HIV infection in Southwestern Uganda." Doctoral Thesis. Boston, MA: Harvard School of Public Health.

Caldwell JC, Caldwell P. (1993). "The nature and limits of the sub-Saharan African AIDS epidemic: evidence from geographic and other patterns." Population and Development Review, 19(4):817-848.

Caldwell JC, Caldwell P, Orubuloye IO. (1989). "The social context of AIDS in subSaharan Africa." Population and Development Review, 15(185):188. 
Demographic Research - Special Collection 1: Article 9

-- Social Interactions and HIV/AIDS in Rural Africa --

Catania J, Kegeles S, Coates T. (1990). "Towards and understanding of risk behavior: and AIDS Risk Reduction Model (ARRM)." Health Education Quarterly, 17(1):53-72.

Cerwonka ER, Isbell TR, Hansen CE. (2000). "Psychosocial factors as predictors of unsafe sexual practices among young adults." AIDS Education and Prevention, 12(2):141-153.

Chirwa I. (1993). "AIDS epidemic in Malawi: shaking cultural foundations." Network, 13(4):31-32.

Connell R. (1987). Gender and Power. Stanford, CA: Stanford University Press.

DiClemente R, Wingood G. (1995). "A randomized controlled trial of an HIV sexual risk-reduction intervention for young African-American Women." JAMA, 274(16):1271-6.

Denison J. (1996). Behavioral change. A summary of four major theories. Arkington: Family Health International/AIDSCAP. Available at http://www.fhi.org/en/aids/aidscap/aidspubs/behres/bcr4theo.html.

Dodoo F, Ampofo A. (1998). "AIDS-related condom use among married Kenyan men." African Population Policy Research Center, Working Paper No.8.

Estrin D. (1999). "In Ghana, young men's condom use is linked to lack of barriers, perceived susceptibility to HIV infection." International Family Planning Perspectives, 25(2):106-107.

Fishbein M, Ajzen I. (1975). Belief, Attitude, Intention and Behavior. Reading, MA: Addison-Wesley.

Fishbein M, Middlestadt SE. (1989). "Using the theory of reasoned action as a framework for understanding and changing AIDS-related behaviors." In: Mays VM, Albee GW, Schneider SF, Eds. Primary Prevention of AIDS: Psychological Approaches. London: Sage Publications: 93-110.

Garnett GP, Anderson RM. (1993). "Factors controlling the spread of HIV in heterosexual communities in developing countries: patterns of mixing between different age and sexual activity classes." Philosophical Transactions of the Royal Society of London: B. Biological Sciences, 342(1300):137-59.

Gillies P, Carballo M. (1990). "Adult perception of risk, risk behavior and HIV/AIDS: A focus for intervention and research [editorial]." AIDS, 4(10):943-51. 
Gregson S, Zhuwau T, Anderson RM, Chandiwana SK. (1998). "Is there evidence for behavioral change in response to AIDS in rural Zimbabwe?" Social Science and Medicine, 46(3):321-330.

Howard M, McCabe J. (1990). "Helping teenagers postpone sexual involvement." Family Planning Perspectives, 22(1):21-26.

Hunt CW. (1996). "Social vs. biological: theories on the transmission of AIDS in Africa." Social Science and Medicine, 42(9):1283-1296.

Kalichman S. (1998). Preventing AIDS: a sourcebook for behavioral interventions. Mahwah, NJ: Lawrence Erlbaum Associates Inc.

Kalichman S, Rompa D, Coley B. (1997). "Lack of positive outcomes from a cognitivebehavioral HIV and AIDS prevention intervention for inner-city men: Lessons from a controlled pilot study." AIDS Education and Prevention, 9(4):299-313.

Kengeya-Kayondo JF, Carpenter LM, Kintu PM, et al. (1999). "Risk perception and HIV-1 prevalence in 15000 adults in rural south-west Uganda." AIDS, 13(16):2295-2302.

Klepinger DH, Billy JOG, Tanfer K, Grady WR. (1993). "Perceptions of AIDS risk and severity and their association with risk-related behavior among U.S. men." Family Planning Perspectives, 25(2):74-82.

Kohler H-P, Behrman JR, Watkins SC (2002). "Social network influences and AIDS risk perceptions: Tackling the causality problem." Paper presented at the annual meeting of the Population Association of America, Atlanta, GA, May 9-11.

Leventhal H (1971). "Fear appeals and persuasion: The differentiation of a motivational construct." American Journal of Public Health, 61(6):1208-24.

Leventhal H, Safer M, Panagis D. (1983). "The impact of communications on the selfregulation of health beliefs, decisions, and behavior." Health Education Quarterly, 10(1):3-29.

London AS, Robles A. (2000). "The co-occurrence of correct and incorrect HIV transmission knowledge and perceived risk for HIV among women of childbearing age in El Salvador.” Social Science and Medicine, 51(8):12671278 .

Lupton D. (1993). "Risk as moral danger: The social and political functions of risk discourse in public health." International Journal of Health Services 23(3):42535 . 
McGrath JW, Rwabukwali CB, Schumann DA, et al. (1993). "Anthropology and AIDS: the cultural context of sexual risk behavior among urban Baganda women in Kampala, Uganda." Social Science and Medicine, 36(4):429-439.

Montgomery MR, Casterline JB, Heiland F. (2001). "Social Networks and the Diffusion of Fertility Control." New York: The Population Council. Available at http://www.popcouncil.org/pdfs/wp/119.pdf.

Morris M. (1997). "Sexual networks and HIV." AIDS, 11(suppl. A):S209-16

Mouli VC. (1992). All against AIDS, the Copperbelt Health Education Project. London: ActionAid.

National AIDS Control Programme [Malawi]. (1998). "HIV/Syphilis Seroprevalence in Antenatal Clinic Attenders." National AIDS Control Programme. Lilongwe.

Njovana E, Watts C. (1996). "Gender violence in Zimbabwe: a need for collaborative action." Reproductive Health Matters, (7):46-55.

Ntozi J, Kirunga C. (1997). "HIV/AIDS, change in sexual behavior and community attitudes in Uganda." Health Transition Review, 7(supplement):157-174.

Ostrow D. (1990). "Psychiatric aspects of AIDS: An overview." In: Ostrow D, Ed. Behavioral Aspects of AIDS. New York, NY: Plenum Publishing Corp.

Packard RM, Epstein P. (1991). "Epidemiologists, Social Scientists, and the Structure of Medical Research on AIDS in Africa." Social Science and Medicine, 33(7):771-794.

Prochaska JO, DiClemente CC, Norcross JC. (1992). "In search of how people change: Applications to addictive behaviors." American Psychologist, 47(9):1102-1114.

Quinn TC. (1994). "Population migration and the spread of types 1 and 2 human immunodeficiency viruses." Proceedings of the National Academy of Sciences of the United States of America, 91(7):2407-2414.

Ray S, Bassett M, Maposhere C, et al. (1995). "Acceptability of the female condom in Zimbabwe: positive but male centered responses." Reproductive Health Matters, May (5):68-79.

Ray S, Gumbo N, Mbizvo M. (1996). "Local voices: what some Harare men say about preparation for sex." Reproductive Health Matters, May (7):34-45.

Rogers EM. (1983). Diffusion of Innovations. Third Edition. New York: The Free Press. 
Rosenstock IM, Strecher VJ, Becker MH. (1994). "The health belief model and HIV risk behavioral change." In: DiClemente RJ, Peterson JL, Eds. Preventing AIDS: Theories and Methods of Behavioral Interventions. New York: Plenum Press.

Taha T, Canner J, Chiphangwi J, et al. (1996). "Reported condom use is not associated with incidence of sexually transmitted diseases in Malawi." AIDS, 10(2):207-12.

Tawfik, Linda (2003). Soap, Sweetness, and Revenge: Patterns of Sexual Onset and Partnerships Amidst AIDS in Rural Southern Malawi. Baltimore, MD, Bloomberg School of Public Health, Johns Hopkins University.

Timmins P, Gallois C, McCamish M, Terry D. (1998). "Sources of information about HIV/AIDS and perceived risk of infection among heterosexual young adults: 1989-1994.” Australian Journal of Social Issues, 33(2):179-198.

UNAIDS. (1999). "Sexual behavioral change for HIV: Where have the theories taken us?" UNAIDS. Geneva.

UNAIDS/WHO. (2000). "Report on the global HIV/AIDS epidemic - June 2000." UNAIDS/WHO. Available at http://www.who.org/.

Van de Wijgert JHHM, Khumalo-Sakutukwa GN, Coggins C, et al. (1999). "Men's attitudes toward vaginal microbicide trials in Zimbabwe." International Family Planning Perspectives, 25(1):15-20.

Vandlandingham MJ, Suprasert S, Grandjean N, Sittitrai W. (1995). "Two views of risky sexual practices among Northern Thai males: the Health Belief Model and the Theory of Reasoned Action." Journal of Health and Social Behavior, 36(March):195-212.

Warriner I, Watkins S. (2000). "How Are Networks Selected?" Philadelphia, PA: University of Pennsylvania, mimeo.

Watkins SC, Schatz E (2001). "Avoiding AIDS: global advice and local strategies." Paper presented at the annual meeting of the Population Association of America, Washington, D.C., March 28-31.

Watkins, Susan C., Eliya M Zulu, Hans Peter Kohler and Jere Behrman. 2003. "Introduction" Demographic Research - Special Collection 1: "Social Interactions and HIV/AIDS in Rural Africa", edited by Susan Watkins, Eliya M. Zulu, Jere Behrman, and Hans-Peter Kohler. http://www.demographicresearch.org 
Demographic Research - Special Collection 1: Article 9

-- Social Interactions and HIV/AIDS in Rural Africa --

Watts C, Keogh, Ndlovu, Kwaramba. (1998). "Withholding of sex and forced sex: dimensions of violence against Zimbabwean women." Reproductive Health Matters, Nov (12):57-65.

Weinstein ND, Nicolich M. (1993). "Correct and incorrect interpretations of correlations between risk perceptions and risk behaviors." Health Psychology, 12(3):235-45.

Williams G, Ray S. (1993). Work against AIDS: Workplace-based AIDS initiatives in Zimbabwe. London: ActionAid. 
Demographic Research - Special Collection 1: Article 9

-- Social Interactions and HIV/AIDS in Rural Africa -- 